\title{
Por uma Arqueologia da Paisagem: mobilidade e enraizamento em perspectiva americana
}

Dossier Rede Urbana e DeFiniÇão das Fronteiras PaULISTAS

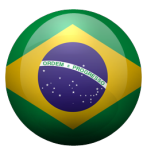

\section{Beatriz Piccolotto Siqueira Bueno}

Professora do Departamento de História da Faculdade de Arquitetura e Urbanismo - Universidade de São Paulo. Doutora em Arquitetura e Urbanismo [FAU-USP], Historiadora [FFLCH-USP]. São Paulo [SP] Brasil <bpsbueno@gmail.com>.

\begin{abstract}
Resumo
A historiografia sobre o processo de urbanização no Brasil no período colonial pautou-se, em geral, pelo estudo das vilas e cidades em detrimento dos demais núcleos de povoamento que pontuavam territórios cumprindo diferentes papéis. Lugares, arraiais, capelas, freguesias, julgados, bairros rurais, aldeias indígenas, aldeamentos missioneiros, pousos, registros, passagens, barreiras, fazendas, sítios, currais e fortalezas ficaram obscurecidos em meio à rarefeita rede de vilas e cidades. A historiografia tampouco deu atencão à natureza da multifacetada teia de comunicação que articulava esses núcleos - rios, córregos, veredas, trilhas, caminhos e calçadas - que permitiam ou dificultavam fluxos e contatos interregionais, em meio à difícil e plural geografia física e humana que até hoje caracteriza as nossas diversas paisagens culturais. Uma série de mapas presta-se de maneira exemplar à reconstituição de uma trama perdida no tempo, por meio de recursos de informática contemporâneos, propiciando estudos quantitativos mais pormenorizados que certamente fundamentarão um olhar qualitativo mais minucioso com foco nas dinâmicas e práticas cotidianas, no ritmo das viagens, na distância entre as localidades, nas dificuldades de contato, no fluxo dos rios, nas barreiras impostas pela topografia e a vegetação ou por grupos humanos, nos pontos de paragem para descanso e pedágio, etc. A visão de conjunto propiciada pelo exame de certos mapas permite assim reconceituar noções como a de "rede" e de "urbano" no Brasil-Colônia, analisando aspectos gerais e especificidades regionais, as diversas escalas, modalidades e temporalidades, propiciando novas hipóteses sobre enraizamento e mobilidade no processo histórico de ocupação e devassamento do território colonial. Estudos dessa natureza realizados por uma nova safra de autores podem assim nos ajudar a responder a pergunta que orienta este artigo: em que medida a colonização do Brasil foi mais urbana e menos arquipelágica do que parecia à primeira vista?
\end{abstract}

\section{Palavras-chave}

Arqueologia da Paisagem. Cultura Material. Urbanização. Rede Urbana. Mobilidade. Iberoamerica. Séculos XVII-VIII.

\section{For a Landscape Archeology: mobility and rooting in American perspective}

\begin{abstract}
The historiography of urbanization in colonial Brazil has largely focused on towns and cities rather than other types of settlements that fulfilled different roles. Localities, camps, chapels, parishes, townships, hamlets, indigenous villages, missionary settlements, landings, passages, barriers, farms and ranches, corrals and fortresses have been overshadowed by a rarefied network of towns and cities. Nor has this historiography examined the multifaceted web of routes between clusters, such as the rivers and waterways, highways and byways, and trails that facilitated or hindered interregional traffic and contacts across obstructive and pluralistic physical geography that even today characterizes our diverse cultural landscape. A series of maps are used to reweave a mesh that had been lost in time; contemporary IT resources enable more detailed quantitative studies that will surely underpin a more detailed qualitative focus on everyday dynamics and practices, the timing and distances involved in journeys between localities, difficulties for contact, varying flows of watercourses, barriers imposed by topography and vegetation, or by human groups, rest-overs and tolls, etc. An overview of certain maps may reconcile notions such as "network" and "urban" in colonial Brazil by analyzing general aspects and regional specificities, varying scales, modalities and temporalities, thus posing new hypotheses about settlement and mobility in the historical process of occupying and exploring colonial territory. Studies of this nature undertaken by new researcher cohorts may help answer the question posed by this article: to what extent was Brazil's colonization more urban and less archipelagic than it appeared to be at first sight?
\end{abstract}

\section{Keywords}

Landscape archeology. Material culture. Urbanization. Urban network. Mobility. Iberian America. 17th and 18th centuries. 


\section{Introdução}

Pensar em métodos de leitura da paisagem e da cultura material nos leva a flertar com a Geografia nas suas interfaces com a História, tal como fez Fernand Braudel em Civilização Material, Economia e Capitalismo: séculos XV-XVIII (Braudel, 1995). Desvelar camadas de tempos e imaginar dinâmicas, lógicas antrópicas de enraizamento e de mobilidade na paisagem significa imaginar fluxos em caminhos e rios nas suas possibilidades e dificuldades de comunicação, em busca dos vestígios de uma fenomenologia dos modos de ser e estar em escala macrorregional. A perspectiva macrorregional e americana impõe-se como um desafio desejável, na medida em que se observa a predominância de uma historiografia brasileira muito regionalizada e segmentada em termos de América Portuguesa e Espanhola1.

Uma nova safra de estudos vem pondo luz em ver relações macroterritoriais inimagináveis e, ao mesmo tempo, permitindo repensar conceitos que engessam a História da Urbanização iberoamericana. Tais estudos recentes permitem entender a rede urbana na sua conotação mais ampla, nela incluindo-se pousos, bairros rurais, fazendas, feiras, passagens, registros e demais pontos nodais relacionados às cidades, vilas, capelas, freguesias, julgados e aldeamentos missioneiros. Isso possibilita ampliar o conceito de urbano para todo e qualquer vestígio indicativo de presença humana irradiada de demandas urbanas, via homens urbanos, a despeito da sua fragilidade demográfica, formal e estatuto político. Esses estudos permitem ainda alargar o conceito de núcleo urbano propriamente dito, ao demonstrar que lhe orbitavam um rosário de bairros rurais, fazendas e sítios que alimentavam mercados distantes. Nesse sentido, achamos pertinente incluir no horizonte das questões citadinas pontos de economia que extrapolavam a lógica da subsistência, dando-lhes visibilidade por estarem imantados a circuitos urbanos e que, em constelação, configuravam territorialidades entretecidas por vivências cotidianas.

Para tanto, a cartografia é fonte privilegiada. Embora exijam críticas internas por sua dimensão retórica, ideológica e por suas agendas ocultas (Harley, 2005), mapas são ímpares na sua capacidade de registrar relações espaço-temporais para se aquilatar práticas e dinâmicas em suas lógicas de funcionamento cotidiano em diversas escalas geográficas. No presente artigo, a ideia é desvelar paisagens pretéritas representadas na cartografia, entendendo-as como configurações territoriais de um "conjunto de elementos naturais e artificiais" e, como tal, uma "espécie de palimpsesto onde, mediante acumulações e substituições, a ação das diferentes gerações se superpõe" (Santos, 1996, p. 104). Em paralelo, ambiciona-se ensaiar possibilidades de interface em escala continental, percebendo fronteiras interimperiais mais porosas do que nos pareciam à primeira vista, aqui entendidas como "zonas de encontro culturais, trocas e hibridismos" mais do que barreiras políticas (Burke, 2006, p. 51-53 e 72-73). Na perspectiva de uma história global ou mundial (Gruzinski, 2014), pretende-se ensaiar romper empiricamente barreiras políticas e historiográficas, imaginando triangulações entre contextos americanos, africanos e asiáticos por intermédio ou não das Coroas ibéricas aos quais estiveram subordinados ao longo do colonialismo.

\section{Uma nova safra de estudos e suas potencialidades interpretativas}

Em 2012, coordenamos o dossiê Caminhos da História da Urbanização no Brasil-Colônia nos Anais do Museu Paulista (Bueno, 2012), dedicado especialmente aos avanços historiográficos sobre a temática nos anos 2000. Curioso perceber àquela altura quanto o campo disciplinar havia crescido desde sua criação por ocasião da tese de livre-docência Evolução Urbana no Brasil 1500-1720 de Nestor Goulart Reis Filho (1964). Passados cinco anos, o cenário parece renovar-se mais uma vez, vislumbrando-se novas veredas muito salutares.

O desafio de explorar um Brasil de dimensões continentais impõe, antes de tudo, um trabalho coletivo para se desconstruir "narrativas" e "lugares comuns" (Bresciani, 2001, pp. 403-429) que

\footnotetext{
10 texto referente a este artigo foi originalmente apresentado sob o título "O Brasil-colônia: em que medida mais urbano do que parece à primeira vista?" na mesa 21 - "Vilas, cidades e território. Diversas escalas de intervenção no Brasil dos séculos XVIII e XIX" - no Primer Congreso Iberoamericano de Historia Urbana, organizado pela Asociación Iberoamericana de Historia Urbana (AIHU), a Universidad de Chile e a Pontificia Universidad Católica de Chile, realizado em Santiago de Chile entre el 23 e 25 de novembro de 2016 e publicado nos Anais do evento, pp. 825-834.
} 
acabaram adquirindo estatuto historiográfico, sobretudo mitos emanados dos institutos históricos e geográficos nacional e regionais. Pesquisas recentes embaçam nossos olhos viciados por certos estereótipos, fazendo saltar à vista novas territorialidades com ramificações bastante alargadas. Sem o saber e desconectados entre si, esses estudos lançam luz em evidências empíricas que merecem debate por seu ineditismo e por conspirarem para uma necessária releitura do Brasil em seu conjunto, inclusive nas suas interfaces com a América Espanhola e com outros continentes:

a) Desmontam a tese da "colonização arquipelágica", rompendo com a ideia de "fragmentação" e "descontinuidade" entre as partes do Brasil.

b) Revelam territorialidades macrorregionais e zonas de intersecção de perfil cultural híbrido, compartilhando hábitos, dialetos e costumes que subvertiam as fronteiras políticas que lhes foram impostas.

c) Permitem refutar narrativas e ideologias emanadas dos Institutos Histórico e Geográficos regionais que, ao construírem as identidades dos Estados da República Federativa então em gestação, isolaram-nos do conjunto, contaminando gerações de pesquisas e pesquisadores igualmente regionalizados.

a) Desmontam axiomas históricos, como ideias de bandeirantes paulistas desbravadores de territórios incógnitos; estanqueidade na divisão técnica e social do trabalho, reforçando a ideia da interdependência entre zonas vinculadas ao comércio atlântico e zonas de abastecimento, fugindo da dicotomia clássica litoral-sertão.

b) Demonstram a interdependência de fluxos que entreteciam o mercado interno ao comércio platino e andino e às outras "três partes do mundo".

c) Esses estudos revelam materialmente formas e tipologias de articulação, inclusive intermodais.

d) Revelam uma diversidade de pontos de enraizamento e mobilidade de uma rede urbana mais plural e interiorizada do que nos parecia.

e) Metodologicamente, têm como denominador comum o gosto pela cartografia que, seriada e cruzada com outras fontes, dá a ver relações espaço-temporais, permitindo mensurar seus graus de incidência.

f) A cartografia mostra-se nesses estudos um documento privilegiado para se imaginar distâncias, aquilatar dificuldades, obstáculos, tempos de viagem, bem como inferir sobre a vegetação, o clima, os índices pluviométricos, o solo, a orografia e as preexistências nativas.

g) Esses estudos nos incitam a "varrer a pé" e a "pensar con los ojos" (Bayón, 1982), despojando-nos da comodidade do gabinete e das bibliotecas cada vez mais agigantadas que nos impõem um sedentarismo nefasto.

h) Ao romper com categorias inertes como "sertão", "homogêneo", "vazio", "incógnito", mostram a pluralidade de paisagens culturais resultantes da interação entre homens e naturezas (ambos no plural). Ousam inclusive desconfiar da homogeneidade da categoria "sertão", bem como dos biomas, mostrando diversidade na aparente homogeneidade.

i) Ao adotar a ideia de "fronteira" como "metáfora do encontro", permitem reavaliar o legado cultural híbrido de zonas de contato interamericano como foram as Capitanias de São Paulo, Mato Grosso e São José do Rio Negro.

j) Numa linha de trabalho braudeliana, buscam explicitar "onde", "quem passava", "o que se transportava" e "como" funcionavam as comunicações entre as partes colônia, dando pistas sobre diferentes tipologias de rotas terrestres e fluviais e de núcleos de enraizamento e mobilidade que garantiam pouso e abastecimento nas jornadas.

k) Por meio do estudo da lógica dos fluxos e dos atores em movimento, permitem imaginar hibridismos na língua, na alimentação e na cultura material em territorialidades outrora lidas numa chave endógena.

l) Muitos desses novos estudos valem-se dos sistemas de informação geo-históricas (SIGs Históricos), ao nosso ver uma ferramenta importante para dar a ver o que de outra forma não se vê e permitir formular novas questões e novas hipóteses para uma História da Urbanização ibero-americana, revelando quantitativa e qualitativamente graus de incidência, georreferenciando e espacializando fontes cruzadas, nem sempre visuais.

m) Esses estudos revelam a interdependência entre os mundos urbano e rural e hoje nos permitem reconceituar a noção de rede urbana, incluindo-se novos núcleos além das tradicionais cidades, vilas, capelas e freguesias. 
n) Permitem inclusive reconceituar a categoria "homens urbanos", nela incluindo homens rurais cujas atividades vinculavam-se ao abastecimento de circuitos urbanos.

o) No que tange à rede urbana, o Atlas Histórico da América Lusa publicado por Tiago Gil e Leonardo Barleta, em 2016, dá a medida da teia de vilas e cidades. Entretanto, por falta de levantamentos sistemáticos Brasil afora, os autores não puderam registrar a rede de lugares, arraiais, capelas, freguesias, julgados, aldeamentos missioneiros, pousos, registros, passagens, fazendas de abastecimento, currais, fortalezas e outros núcleos de povoamento e mobilidade que dariam um quadro mais completo da urbanização, permitindo rever a geografia do colonialismo, a nosso ver, menos arquipelágica e mais integrada. Obviamente essa tarefa hercúlea demanda equipes integradas. Nesse sentido, revelam-se promissores os esforços de alguns autores em enriquecer a trama, apertando sua urdidura e expandindo-a em todas as direções.

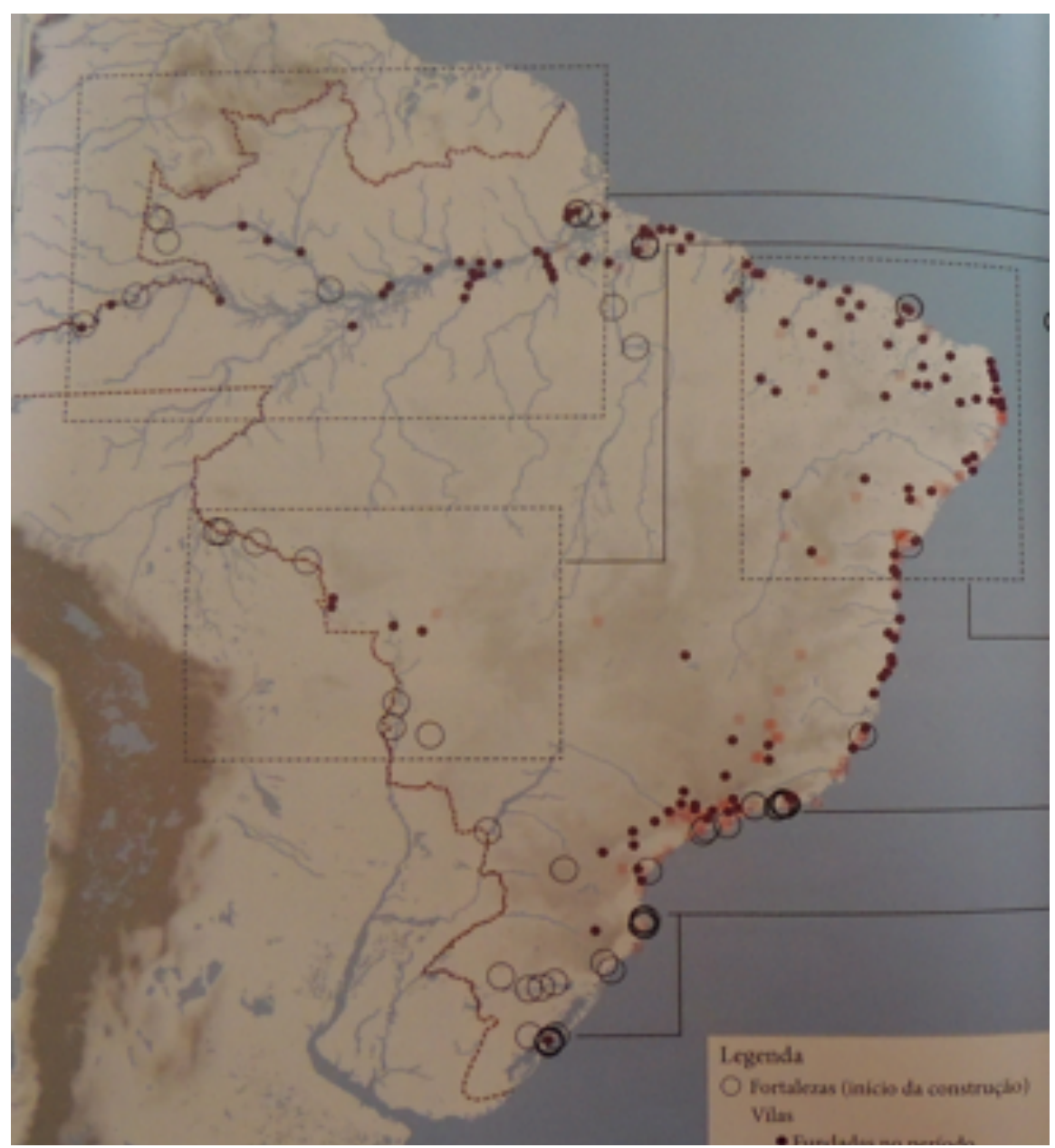

Figura 1. Mapa da rede de vilas e cidades do Brasil no período colonial. Fonte: T. Gil, \& L. Barleta. Atlas histórico da América lusa. Porto Alegre: Ladeira Livros, 2016.

\section{A leitura de São Paulo como entroncamento versus o mito do isolamento e da estagnação}

Iniciamos pela Capitania de São Paulo por se tratar do objeto do presente dossiê. No livro Sobre taipas e textos, Rodrigo Silva (Silva, 2013) realiza pertinente balanço historiográfico, propondo uma revisão da narrativa da "São Paulo isolada e estagnada", demonstrando tratar-se de uma construção histórica que acabou ganhando estatuto historiográfico. Gestada no último quartel do século XVIII por Pedro Taques Paes Leme, tal narrativa - segundo o autor - reforçou os feitos de uma nobreza da terra relacionada ao bandeirismo, então decadente, num velado jogo de afirmação de grupos do Seiscentos em face de novos atores do Setecentos - especialmente negociantes portugueses natos envolvidos com o comércio que paulatinamente afirmavam-se financeira e politicamente. Fundamentam a hipótese de Rodrigo Silva uma safra de estudos sobre São Paulo que, na contramão do discurso propalado pelo Morgado Mateus (1765-1775) e seus contemporâneos no momento da Restauração 
da Capitania - sequenciado por uma geração clássica de historiadores do Museu Paulista e do Instituto Histórico e Geográfico de São Paulo -, explora a vocação articuladora de São Paulo nas suas interfaces com outras capitanias, com Angola, com a Bacia Platina e o circuito andino.

Dentre os estudos que alicerçam as hipóteses de Rodrigo Silva, estão os pioneiros a desmontar a tese do bandeirismo e do isolamento de John Monteiro (1994) e Ilana Blaj (2002): o primeiro, ao recuar ao Seiscentos e mostrar o apresamento de indígenas - aparentemente a única economia de sustentação da Capitania de São Vicente - na sua interdependência com a até então desconhecida economia do trigo no planalto, devotada ao abastecimento de um mercado interno aparentemente inexistente; a segunda, ao demonstrar empiricamente o papel de São Paulo na lógica dos fluxos na primeira metade do século XVIII, na sua vocação de entroncamento de um efervescente mercado interno para abastecimento especialmente das áreas de mineração.

Nessa senda alinham-se outros tantos estudos mais recentes. Recuando ao século XVI, Nestor Goulart Reis revelou mineração na Paulistânia, economia vista até então como episódica e inferior à das Minas Gerais, do Mato Grosso e de Goiás. Em As minas de ouro e a formação das Capitanias do Sul (Reis, 2013), o autor comprova empiricamente a longevidade de práticas de mineração nos arredores de São Paulo no século XVI até o século XIX, envolvendo o Jaraguá, Embu, Guarulhos, Araçoiaba, Santana de Parnaíba, entre outras zonas da nossa atual região metropolitana. Em paralelo, revela a interdependência dessa Paisagem Cultural com os negros da terra, principal mão de obra das atividades econômicas em curso, bem como aliados na lógica de sobrevivência em sertões tão dilatados.



Figura 2. Mineração nos arredores de São Paulo, segundo Nestor Goulart Reis, 2013.

Figura 3. Pontos de mineração na região do Embú, segundo Nestor Goulart Reis, 2013.

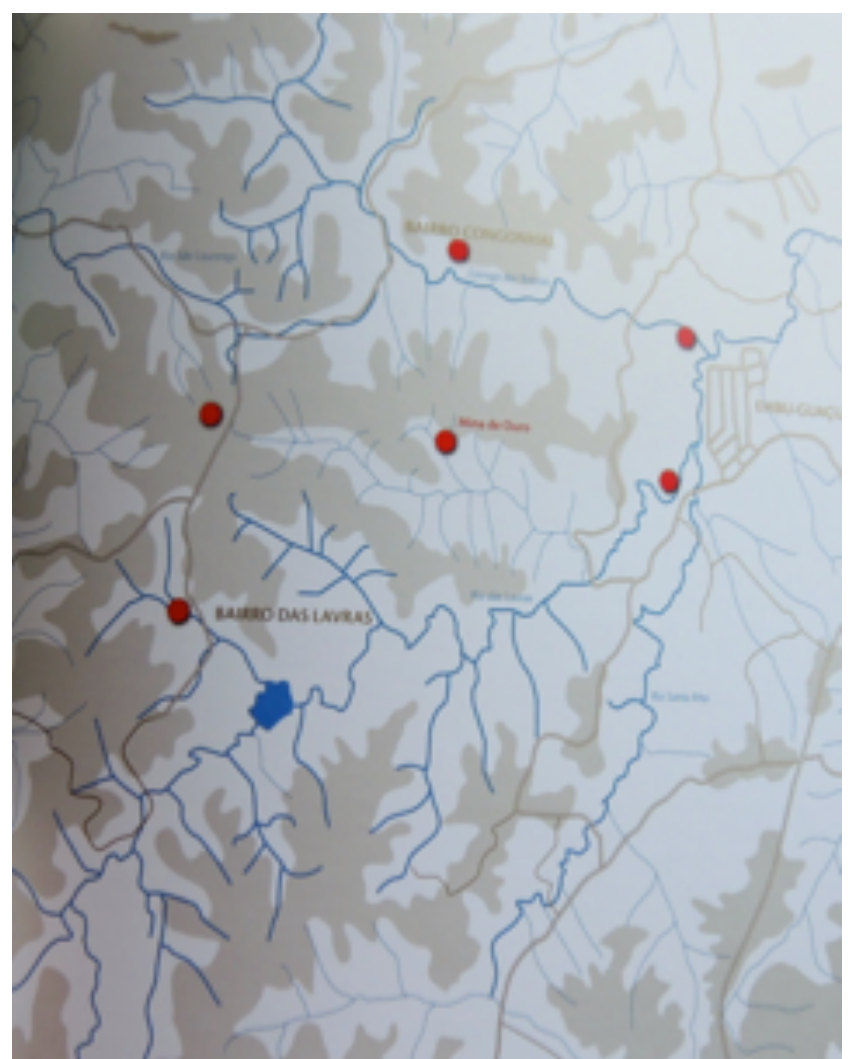

Em seu estudo, Nestor Goulart Reis Filho chama a atenção para as pesquisas de Rubens Gianesella (Gianesella, 2008), mostrando como os indígenas foram fundamentais no cotidiano de existência e sobrevivência nessa paisagem cultural, rompendo com o estereótipo da "tabula rasa" - recorrente na historiografia - que considerou em geral a América um continente vazio. Valendo-se da contribuição de arqueólogos, antropólogos e geógrafos, Rubens Gianesella deixa claro como os ádvenas - quase sempre - elegeram para espaços de vivência certos nichos ecológicos e trilhas indígenas, propondo um novo olhar sobre a aparente simplicidade dos nossos primeiros núcleos e trilhas antigos, mostrando as lógicas que presidiam escolhas e apropriações por parte dos colonos em simbiose com preexistências nativas. 
Ao nosso ver, desde os primeiros tempos, os mais ínfimos e pequenos assentamentos, com baixas densidades demográficas e aparência aquém do estereótipo citadino, por sua capacidade de irradiação de urbanidade em escalas regional e até intercontinental, deveriam ser considerados na chave da hipótese de um Brasil-Colônia mais urbano e menos arquipelágico do que nos parecia à primeira vista. Se atentarmos para a cultura material, a singeleza dos núcleos vicentinos pode obscurecer suas precoces interfaces macrorregionais. No entanto, as entrelinhas do discurso retórico da arquitetura por vezes contradiz a tese do isolamento e da pobreza. Esse é o caso, por exemplo, de Santana de Parnaíba e capelas rurais vizinhas, como a do Voturuna ou a capela dos Jesuítas no Embu. Os retábulos dourados e policromados, bem como a imaginária, revelam riqueza e circulação de referências eruditas em solos da Paulistânia. A sacristia da capela do Embu revela também as interfaces dos jesuítas não só com seus vizinhos paraguaios, mas com um circuito asiático que o Brasil comungava ao fazer parte do império luso e, por certo tempo, do império ibérico (1580-1640), ambos de proporções planetárias. 0 tigre vermelho é uma das tantas chinesices em voga no período e os brutescos do teto da sacristia do Embu metáfora da mais representativa relação com a cultura das grotescas italianas aclimatadas em solos da América Portuguesa <www.hpip.org $>$, certamente financiados pelo ouro minerado nessas paragens.

Com foco nas interfaces interimperiais, importante é o trabalho de José Carlos Vilardaga (2014), o primeiro a ousar interpretar São Paulo na sua vocação de articulação interamericana, pensando a América na sua dimensão continental, ao nosso ver o grande desafio ao qual a historiografia não pode furtar-se de ora em diante. José Carlos Vilardaga empiriciza a interdependência entre o circuito platino, vicentino, angolano e o Rio de Janeiro no período da União das Coroas Ibéricas (1580-1640). Via rios Tietê ou Ivaí ou Piqueri acessava-se o rio Paraná e deste o rio Paraguai, atingindo-se Assunção e as Minas de Potosí. Havia ainda peabirus que margeavam o rio Paranapanema e permitiam acesso à Assunção por via terreste. Da mesma forma, pela costa, podia-se acessar Buenos Aires e Montevidéo. O comércio atlântico e andino articulava-se via Capitania de São Vicente, envolvendo modalidades oficiais e muito "contra bando", inclusive contando com a conivência das autoridades metropolitanas de ambas as coroas, aparentadas por meio de matrimônios com as elites regionais e cariocas. Nessas zonas de fronteira, no chamado Guairá, falava-se um "castelhanês-guarani" fruto de processos de fertilização mútua entre os tantos atores envolvidos. Em seus estudos mais recentes, José Carlos Vilargaga (2016) apoia-se nas contribuições de Nestor Goulart Reis Filho (Reis, 2013) sobre a mineração nas capitanias da Repartição do Sul, demonstrando como o ouro extraído nos arredores de São Paulo, no Paraná e em Santa Catarina, funcionou como moeda de troca no comércio platino e andino, financiando a compra de artefatos e muita prata.

Na mesma direção, os estudos de Fernando de Aguiar Ribeiro (Ribeiro, 2015) mostram-se igualmente instigantes, ao demonstrar relações parentais de famílias paraguaias e parnaibanas, com ênfase no caso dos Fernandes, fundadores das Vilas de Santana de Parnaíba, Itu e Sorocaba (herdeiros de Suzana Dias, típica filha da terra vinculada ao cacique Tibiriçá, casada em primeiras núpcias com um português e em segundas núpcias com um castelhano do Guairá). Mostra que os negócios dos Fernandes (sobrenome inclusive de raiz castelhana) envolviam o apresamento de índios no Guairá, mineração, plantações de trigo e engenhos de aguardente e açúcar, dando pistas sobre as relações continentais de uma gente oriunda de núcleos de feição modesta, mas com articulações de amplo alcance.

Nessa linha destacam-se também os trabalhos recentes de Denise Soares de Moura (Moura, 2012, p. 73-93), nos quais analisa o papel de uma simples freguesia nos arredores de São Paulo - a Freguesia do Ó - na produção e comércio da aguardente, entre 1765-1822, para fins de triangulação com o tráfico negreiro envolvendo Angola e Buenos Aires. Para tanto, foram mobilizados os Maços de População da capital, especialmente do ano de 1802, e os mapas de importação e exportação da vila de Santos produzidos por sua alfândega para a Real Junta de Comércio, no Rio de Janeiro. Essa documentação revelou o caráter estratégico da aguardente no tráfico de escravos para os portos platinos de Montevidéu e Buenos Aires, funcionando como moeda de troca. 0 estudo ganhou novos contornos no ensaio no qual a autora trata da vocação de Santos como um porto entre dois impérios - o português e o espanhol (Moura, 2017).

No que diz respeito às fontes, essas pesquisas não só propõem a combinação de uma variada gama de documentos - oficiais e extra-oficioais - , como permitem olhar a cartografia de outros pontos de vistas.

(C) Labor \& Engenho, Campinas [SP] Brasil, v.11, n.3, p.242-262, jul./set. 2017. 
Nesse sentido, a primeira Carta Geral do Brasil, de 1797, conhecida como Nova Lusitânia, por seu caráter de conjunto, revela possibilidades de análise até aqui inimagináveis.

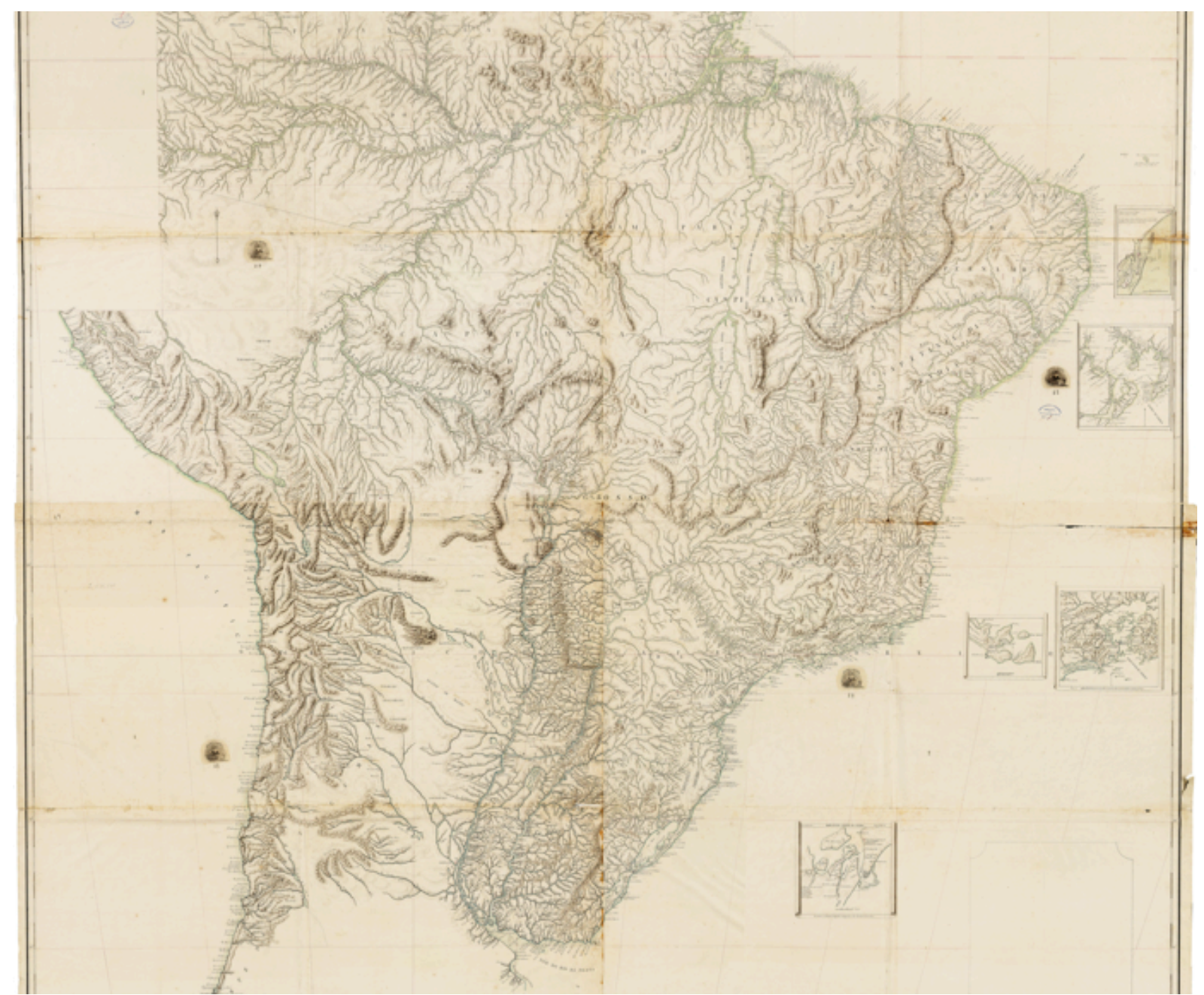

Figura 4. [Carta Geral do Brasil] [1797]. Escala [ca.1:2 600 000], 5 graus de latitude $=[21.7 \mathrm{~cm}]-1$ mapa em 16 folhas coladas : ms., color. ; 199 x 202 cm.; Direcção da Arma de Engenharia.

Visto de longe, esse mapa representa um emaranhado de rios; de perto, revela a urdidura de um Brasil articulado de Norte a Sul e de Leste a Oeste por farta rede hidrográfica articulada a uma nada desprezível rede de caminhos terrestres. Um zoom nos pormenores da Nova Lusitânia permite ver a trama das articulações. Por exemplo, no que tange à Capitania de São Paulo (que nessa altura envolvia o Paraná), revela a interdependência entre as bacias dos rios Grande, Tietê, Paraná e Paraguai, e assim as interfaces entre São Paulo e Assunção e dali com o circuito platino e andino, tanto por terra como por água.

Via sertões do Ivay, acessava-se por terra Assunção do Paraguay e as Missões Jesuíticas ali existentes, envolvendo grandes núcleos de povoamento jesuíticos como Ciudad Real e Vila Rica, igualmente devotados à mineração e ao criatório. Não por acaso, a região foi alvo da política de definição de fronteiras encabeçada pelo Governador da Capitania de São Paulo, D. Luiz Antonio Botelho de Souza e Mourão - o Morgado de Mateus (1765-1775) — durante o consulado pombalino, e objeto de inúmeras expedições de reconhecimento e legitimação de posse (Kok, 2004).

Em termos metodológicos, para realizar a "arqueologia da paisagem" proposta no presente artigo, interessante é cotejar os mapas à documentação que lhe vinha anexa - sem a qual a cartografia não se explica -, bem como dar-lhes vida por meio dos fluxos e dinâmicas dos viandantes que percorreram esses dilatados sertões. Nesse sentido, os relatos das expedições analisados por Glória Kok no livro $O$ sertão itinerante (2004) são fundamentais, dentre eles especialmente os relacionados às expedições ao Ivay e ao Iguatemy. Sobre a última, incontornáveis são os relatórios dos engenheiros militares Teotônio José Juzarte e José Custódio de Sá e Faria (Bueno, 2009). 
Interessante também é confrontar esses mapas com os relatos e à iconografia dos viajantes do século XIX (Spix \& Martius, Ender, Pohl, Saint Hilaire, Kidder, Hercules Florence, William Jonh Burchell, Charles Landseer, etc) que, embora mais distantes no tempo, revelam pormenores do cotidiano das viagens, das tropas, dos tropeiros, dos comboios e dos inúmeros atores envolvidos, na maioria índios e mamelucos.

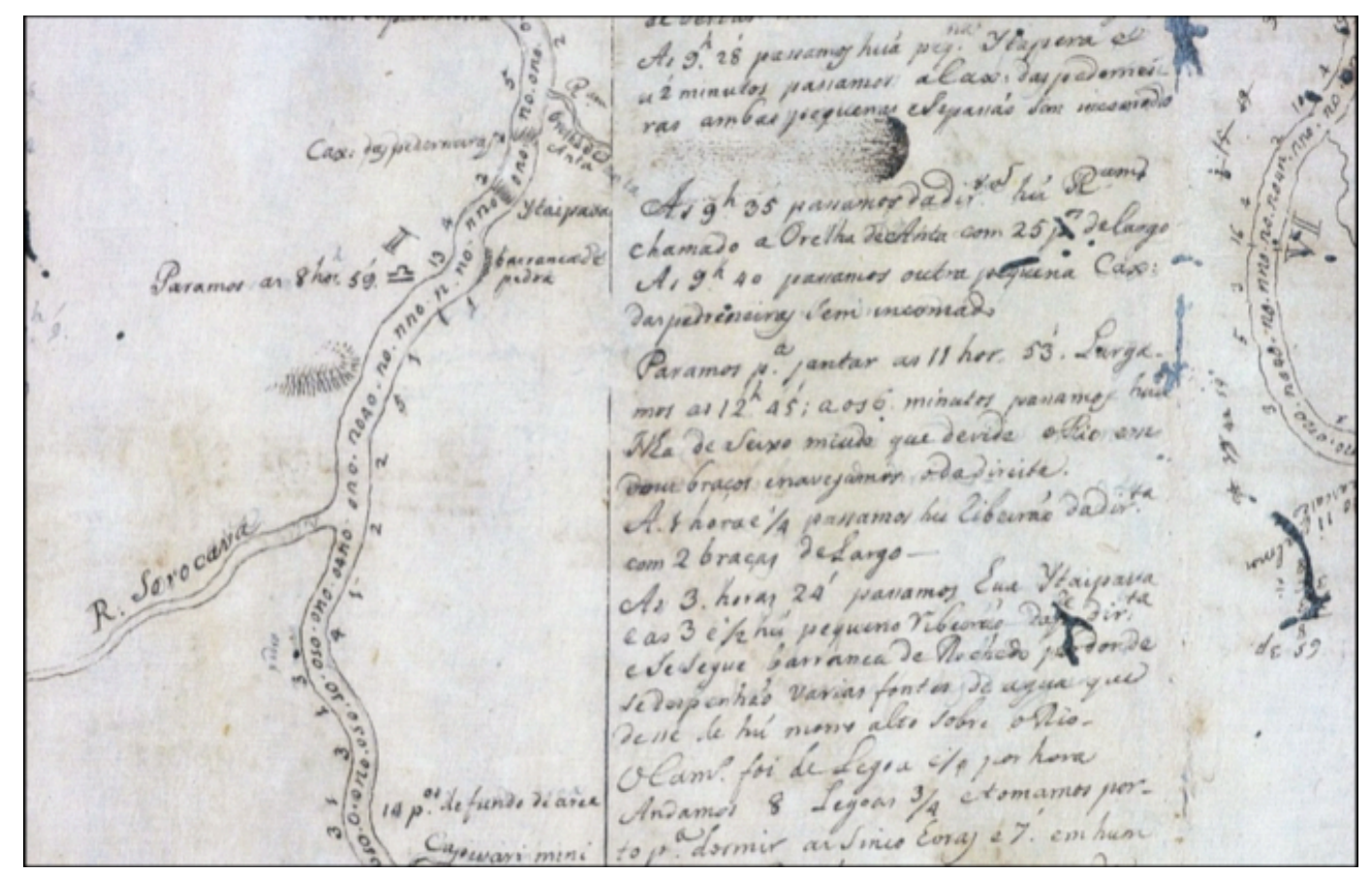

Figura 5. Detalhe do Relatório de José Custódio de Sá e Faria, referente à expedição ao Iguatemy, em 1774. Original pertencente à Mapoteca do Itamaraty-RJ. Fonte: BUENO, Beatriz. Do borrão às aguadas. Anais do Museu Paulista, v. 17, n. 2, 2009.

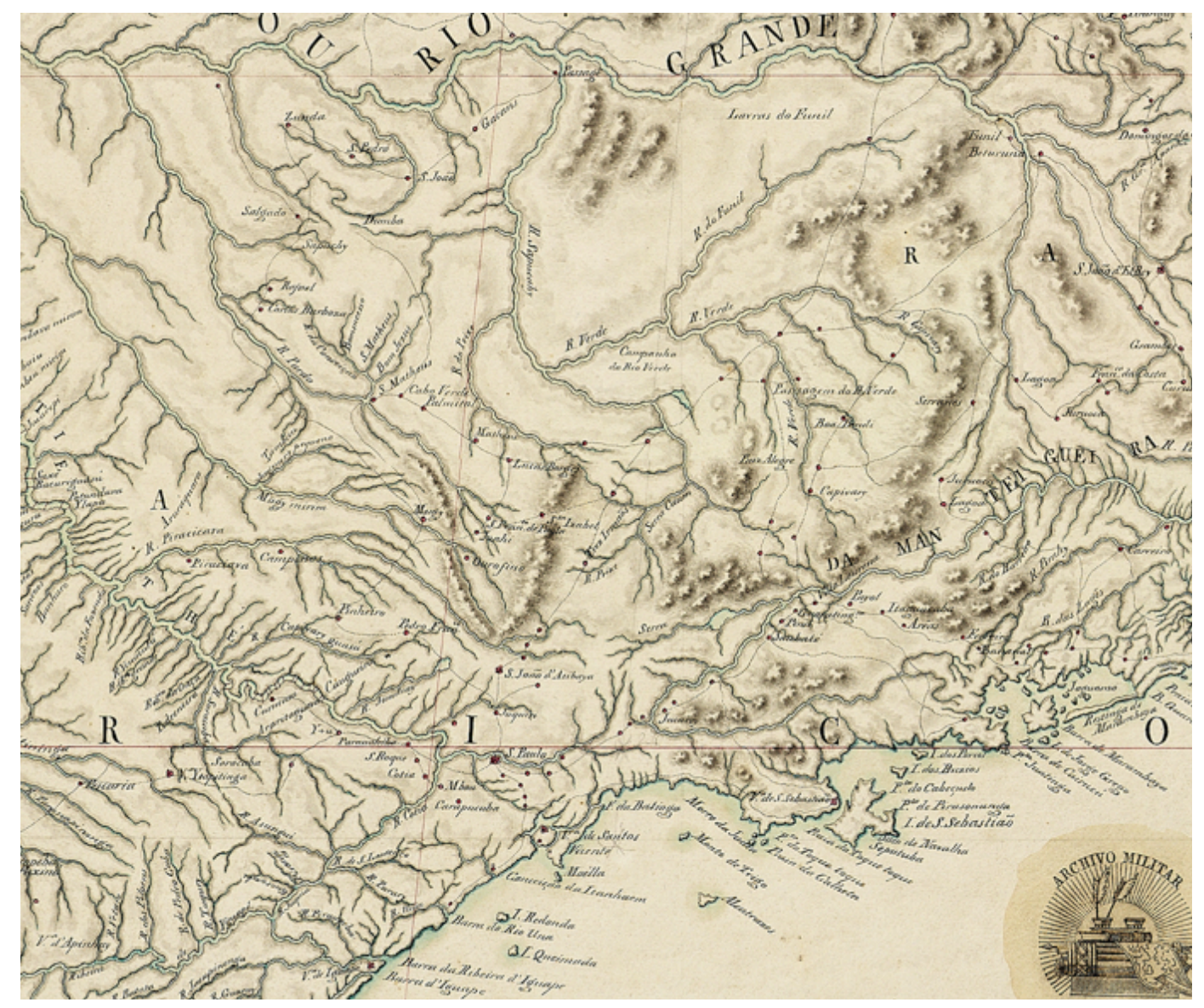

Figura 6. Detalhe da [Carta Geral do Brasil] [1797]. Escala [ca.1:2 600 000], 5 graus de latitude = [21.7 cm]. - 1 mapa em 16 folhas coladas : ms., color. ; 199 x 202 cm.; Direcção da Arma de Engenharia. 


\section{Labor \& Engenho}

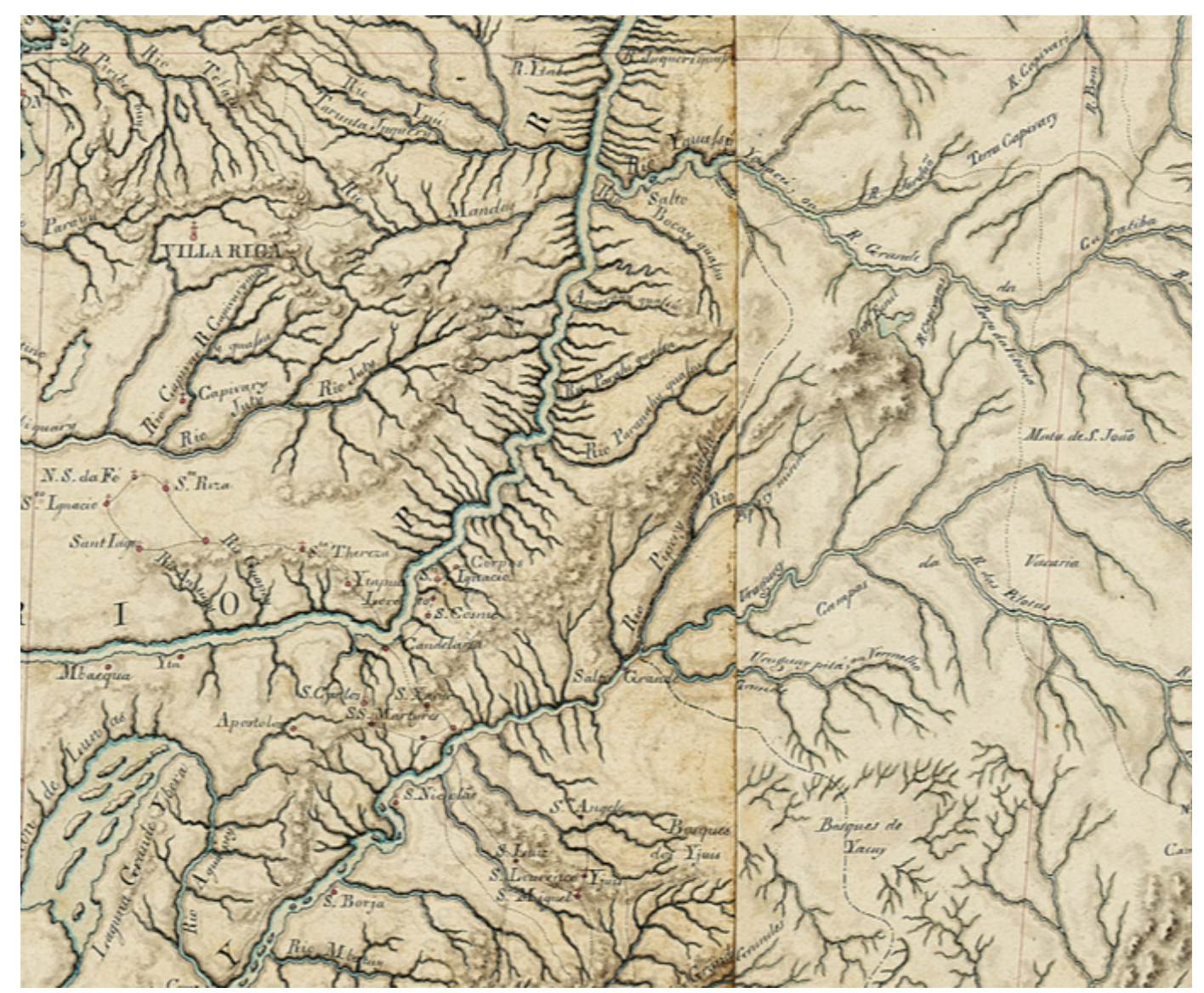

Figura 7. Detalhe da [Carta Geral do Brasil] [1797]. Escala [ca.1:2 600 000], 5 graus de latitude $=[21.7$ cm]. - 1 mapa em 16 folhas coladas : ms., color. ; 199 x 202 cm.; Direcção da Arma de Engenharia.

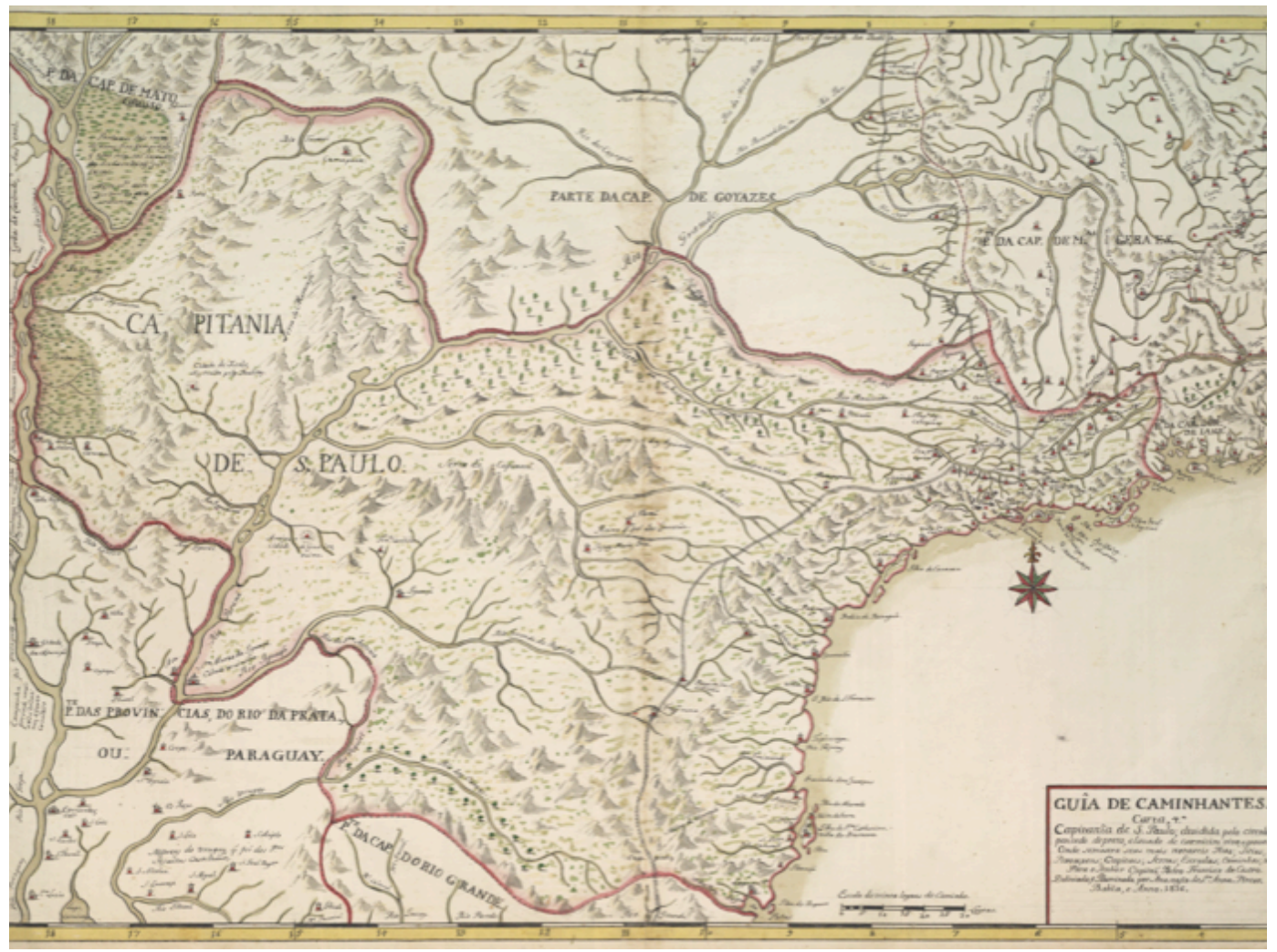

Figura 8. [Guia dos Caminhantes], séc. XIX. Fundação Biblioteca Nacional - RJ. In: KANTOR, Iris. Cartografia e diplomacia: usos geopolíticos da informaçõ toponímica (1750-1850). Anais do Museu Paulista, São Paulo, v. 17, n. 2, p. 39-61, jul.-dez. 2009. Scielo. 
Para além da cartografia e dos relatos oficiais, interessante é contemplar também outros gêneros de documentos, como por exemplo o Guia dos Caminhantes, idealizado para orientar comerciantes nas suas jornadas (Kantor, 2009).

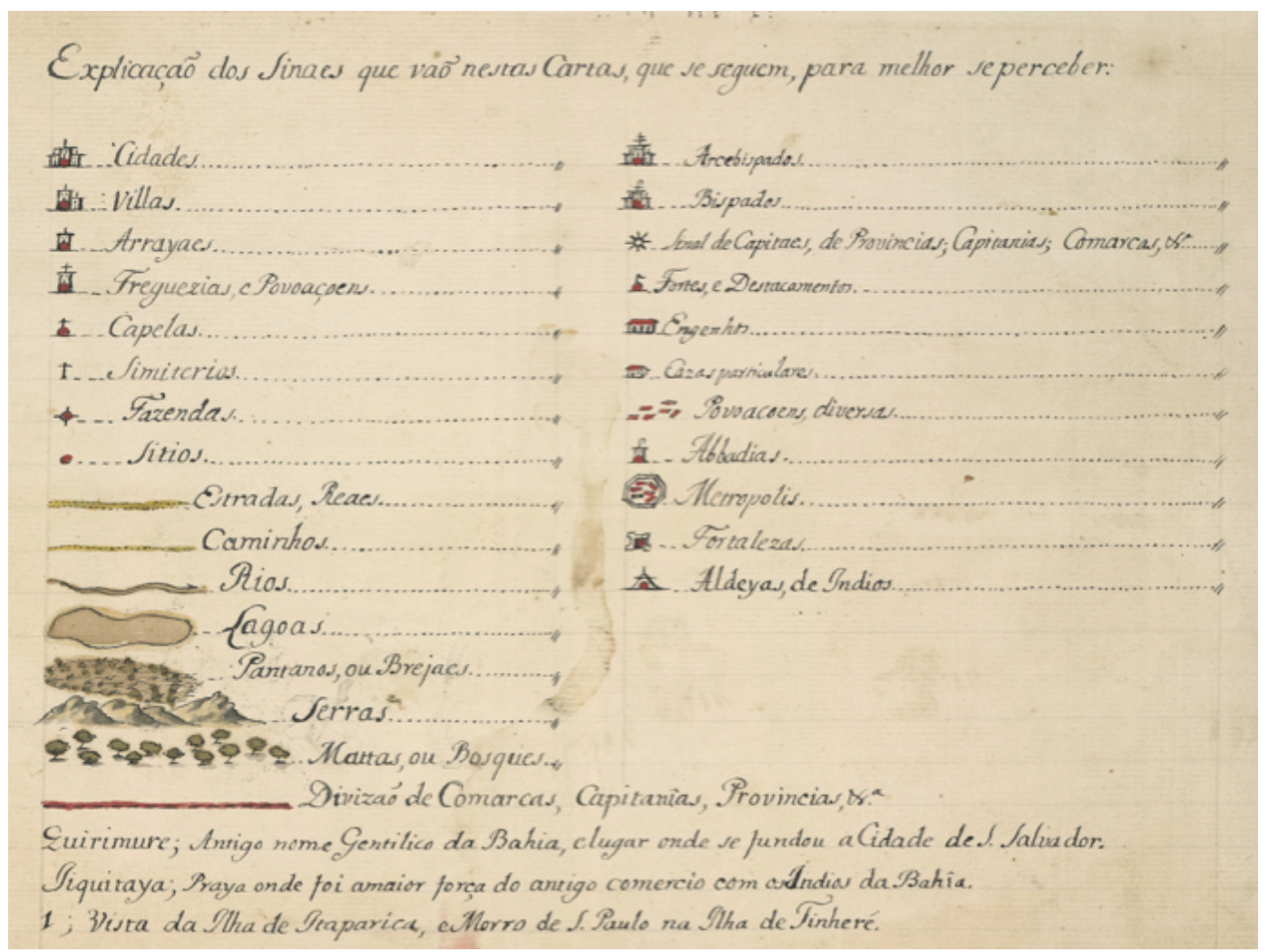

Figura 9. Rede de pontos de paragem nas viagens pelos sertões. [Guia dos Caminhantes], séc. XIX. Fundação Biblioteca Nacional [RJ]. Fonte: Iris Kantor. Cartografia e diplomacia: usos geopolíticos da informação toponímica (1750-1850). Anais do Museu Paulista, São Paulo, v. 17, n. 2, p. 39-61, jul.-dez. 2009. Scielo.

Outra fonte preciosa são os inventários post-mortem dos negociantes envolvidos. Com base nesse tipo de documento, metodologicamente incontornável é o estudo de Maria Aparecida Borrego (Borrego, 2010) que, além de revelar a origem portuguesa desse grupo, pôs luz na cultura material e no conteúdo dos artefatos encontrados nas lojas de São Paulo e nas bagagens dos viandantes, comercializados desde Rio de Janeiro até as minas de Goiás e Mato Grosso na primeira metade do século XVIII (Borrego, 2016).

Também com base nos inventários post-mortem, completa o cenário dessa rede de abastecimento de larga escala o livro de Lucília Viveiros de Araújo (2006) ao focar os negociantes da segunda metade do século XVIII - muitos deles portugueses natos chegados numa segunda leva de imigração e envolvidos com o comércio marítimo internacional e seus desdobramentos no circuito regional. Ampliando o quadro, põe luz em negociantes de grosso trato envolvidos com a produção do açúcar, com o tropeirismo, com o abastecimento, com o tráfico negreiro, com negócios imobiliários e empréstimo de dinheiro a juros, atividades essencialmente urbanas e relacionadas em grande parte ao mercado interno.

Nesse diapasão, Renato de Matos (Matos, 2015) estuda a articulação entre projetos políticos e interesses mercantis radicados em São Paulo, Rio de Janeiro, Lisboa e Porto desde a década de 1780 até as vésperas da Independência, em paralelo à análise da trajetória dos principais negociantes paulistas envolvidos no comércio marítimo realizado na capitania. Dentre eles, merecem destaque alguns nomes, como o cel. Luiz Antônio de Souza - de longe a maior fortuna de São Paulo -, José Arouche de Toledo Rendon, José Vaz de Carvalho, João Lopes França e Nicolau Pereira de Campos Vergueiro.

Em nossos estudos sobre a Décima Urbana de 1809 (Bueno, 2016) esses nomes aparecem como grandes proprietaries detentores de imóveis para fins rentistas. Localizamos conjecturalmente suas moradias e as áreas de incidência do seu patrimônio, percebendo as interfaces dos seus negócios 
para além de São Paulo. A espacialização do Imposto Predial de 1809 na Planta da Cidade de São Paulo do Engenheiro Carlos Bresser, de 1844-1847, possibilitou um retrato da materialidade da cidade, apresentando $86 \%$ de imóveis residenciais e 10\% de imóveis de uso misto concentrados nas principais ruas de comércio - Ruas Direita, Rosário, Comércio (atual Álvares Penteado), Travessa do Comércio (atual Quitanda), Ouvidor e Travessa das Casinhas (atual Rua do Tesouro). A tese da estagnação não se sustenta diante da materialidade de um núcleo cujos imóveis mais caros são aqueles devotados ao comércio de gêneros variados. A Rua Direita polarizava lojas de fazendas secas importadas do Rio de Janeiro, estabelecimentos pertencentes a senhores de engenhos certamente devotados ao comércio e embarque do açúcar e do aguardente, de tropeiros para tratar da circulação dos muares e de cargas, lojas de ferragens e demais entrepostos do comércio internacional e regional. Por sua vez, a rua do Comércio (atual Álvares Penteado) aparece mais especializada na venda a retalho de gêneros de menor monta e a Travessa do Comércio (atual rua da Quitanda) voltada ao comércio de molhados, em vendas e botecos. Já a Travessa das Casinhas envolvia um conjunto de dez imóveis pertencentes à municipalidade dedicados ao comércio de gêneros da terra vindos do entorno para abastecimento da cidade. Ao que tudo indica, essas lojas e vendas recebiam e distribuíam produtos, empiricizando a tese de uma São Paulo com vocação de entroncamento e distribuição macrorregional.

Com foco na materialidade e refutando a tese da pobreza, do isolamento e da estagnação, os estudos de Allan Kato (2017) mostraram também São Paulo em transformação, com imóveis sendo reformados, alteados, fundidos e arquitetonicamente renovados para abrigar essas novas elites em processo de afirmação. Kato, ao comparar as Décimas de 1809 e 1829, revela inclusive o crescimento da cidade em diversas direções nesse período. Nosso estudo sobre as Décimas de Santos completam o cenário de interdependência entre a cidade de São Paulo e seu porto, mostrando os homens de negócios com propriedades lá e cá (Bueno, 2016).

Por sua vez, alguns estudos salientam a interdependência entre o mundo urbano e o rural, mostrando a concomitância de certos atores em ambos, por se tratar de um periurbano relacionado mais ao abastecimento do que à subsistência malgrado a aparência singela dos núcleos em questão. Nesse sentido, orientamos alguns trabalhos com foco em cidades aparentemente inexpressivas na lógica da rede urbana da Paulistânia, como o caso da Freguesia do Facão, depois Vila de Cunha. Lastreado nas Décimas Urbanas (impostos prediais) e nos Maços de População, Diogo Borsoi (2010) mostrou a interdependência entre o mundo urbano e bairros rurais, capelas, sítios e fazendas que lhe rodeavam, redimensionando o papel de uma simples povoação como Cunha entre as vilas de serra acima e os portos da marinha. As décimas revelam significativo conjunto de "lavradores" que ali residiam "quando vinham à vila". Seu cabedal envolvia criação de porcos e plantio de milho com auxílio de 10 a 30 escravos africanos, o que nos levou a suspeitar de não se tratar de homens restritos à economia de subsistência. Descobre-se assim uma rentável rede de abastecimento do Rio de Janeiro pós chegada da Corte - via porto de Paraty —, sobretudo assentada na "indústria do toucinho", daí os porcos, o milho e os tantos escravos, o que nos permite repensar o conceito de urbano e de homens urbanos, ampliando seu escopo para segmentos aparentemente exclusivamente devotados ao universo rural.

\section{A Capitania de Goiás e sua vocação de roldana macroterritorial}

A mesma interdependência de economias aparece nas pesquisas de Nádia Mendes de Moura ${ }^{2}$ ao focar a Capitania de Goiás, segundo ela também devotada à distribuição de gêneros para além da mineração e do criatório. Seu estudo está revelando duas Paisagens Culturais distintas, sabiamente sequenciadas pela Coroa em Comarca do Sul e do Norte. A do Sul tinha uma nítida articulação com São Paulo e Minas Gerais e mostrava-se mais afeita à mineração e ao comércio, inclusive abastecendo o Mato Grosso via São Paulo; a do Norte, articulava-se ao Pará via rio Tocantins, navegável entre Meia Ponte (Pirenópolis) e Cametá, bem como à Bahia por meio de rotas terrestres que conectavam as bacias do Tocantins à do rio São Francisco, com cabeça no Julgado de Natividade, sobretudo em fins do século XVIII. Nesse sentido, aponta para a vocação da capitania de Goiás como roldana macroterritorial, nó de entroncamento e articulação de caminhos terrestres e fluviais em escala macroterritorial, conectando do Viamão ao Pará, do litoral ao Mato Grosso por meio do Julgado de Meia-Ponte (Pirenópolis).

\footnotetext{
${ }^{2}$ Doutorado em andamento na FAUUSP, sob orientação de Beatriz P. S. Bueno.
} 
Sobre o caminho por terra que articulava São Paulo à Capitania de Goiás, importante é o recente estudo de Nestor Goulart Reis Filho $O$ Caminho do Anhanguera (Reis, 2014) que, com base na farta iconografia legada por William John Burchell e outros viajantes, dá materialidade aos núcleos envolvidos, inclusive aos pousos. A viagem de Burchell de Santos a Belém via Natividade, mostra ser este um caminho intermodal recorrente a partir de fins do século XVIII, evidenciando a vocação de articulação do mais extremo sul ao mais extremo norte da colônia, reforçando assim a tese de Nádia Mendes de Moura.

Sobre o caminho por água de Natividade a Belém, estudo interessante é o de Junia Furtado (2016, p. 367-399) sobre o papel do rio Tocantins como articulador macrorregional. Com foco na Carte manuscrite de la navigation de la rivière des Tocantins (c. 1735-1742), mostra o curso do rio e seus tributários, do arraial da Meia Ponte (Pirenópolis), em Goiás, bem próximo de sua nascente, até a vila de Cametá, já na foz do rio Amazonas. Esse longo mapa foi interpretado à luz do manuscrito Roteiro da derrota do rio Tocantins até Belém do Pará que descreve uma expedição que desceu o rio Tocantins, da nascente em Meia Ponte até Cametá, totalizando quase três meses de árdua jornada, entre 2 de novembro de 1734 e 23 de janeiro do ano seguinte, quando atingiu Belém do Pará. Mapa e Roteiro são cotejados ainda com o Roteiro de viagem de José da Costa Diogo e João (sic) Barbosa, sobre a derrota do rio São Francisco pelo rio Urucuya até as Minas de Goyases em 1734. Com a sagacidade que lhe é peculiar, Junia Furtado mostra por meio desse conjunto documental a integração entre duas bacias macrorregionais, bem como as formas transitórias e permanentes de colonização que iam se estabelecendo ao longo desses rios, como fazendas, núcleos urbanos e casas-fortes para proteção contra o ataque de gentios. José da Costa Diogo e seus companheiros se deparam com catas auríferas já exploradas, fazendas e núcleos de povoamento instalados no rio e proximidades, cuja população fora atraída pela mineração e pela cultura do gado. Os estudos de Junia Furtado também permitem rever outra "tópica" emanada dos Institutos Histórico Geográficos, a dos "bandeirantes paulistas" como desbravadores de territórios vazios. Quando os atores supracitados chegaram ao Tocantins, já havia fazendas, mineração, currais de gado instalados por gente proveniente do rio São Francisco.

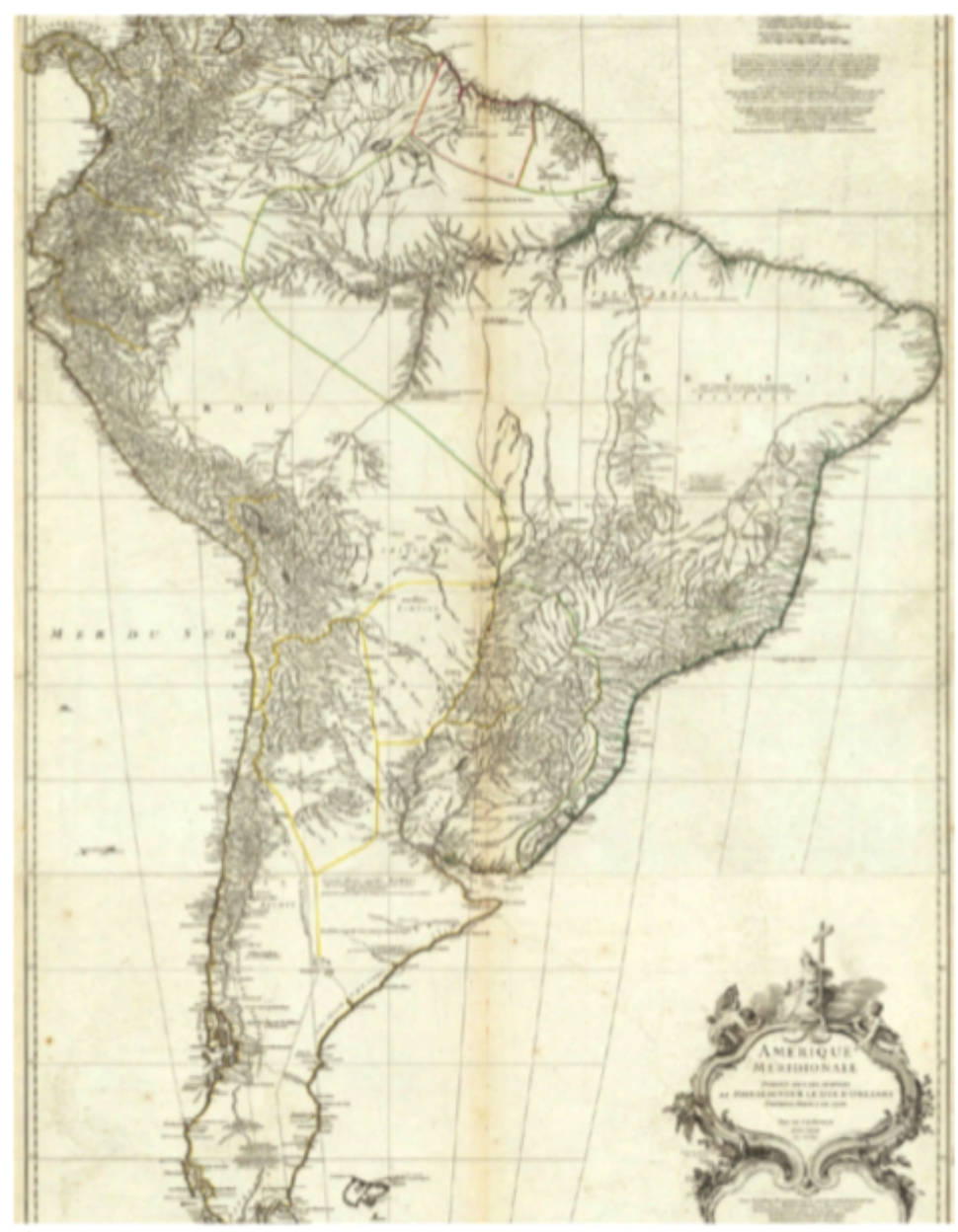

Figura 10. Mapa de Dainville, no século XVIII, revela a centralidade do Rio Tocantins e seu papel articulador. Fonte: Junia Furtado. Metamorfoses da colonização: o rio Tocantins e a expansão para o oeste em mapas e relatos (século XVIII), Tempo (Niterói, online), vol. 22, n. 40, p. 367-399, mai-ago., 2016. 


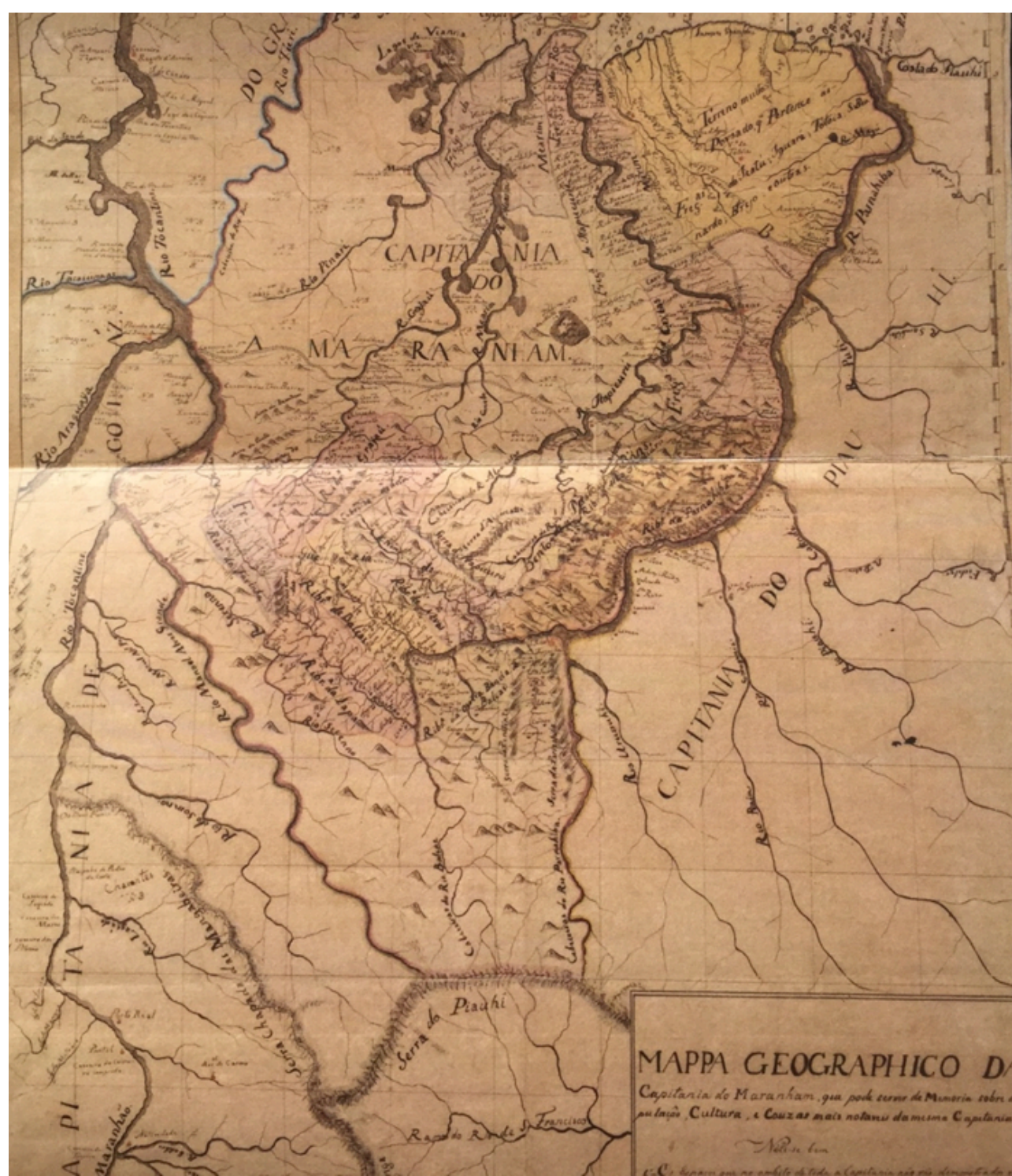

Figura 11. O mapa parece um coração pulsante, cheio de artérias macroterritoriais. À esquerda, sobressai o Rio Tocantins como vertebrador de um amplo território envolvendo as capitanias do Maranhão, Piauí e Goiás. Fonte: RIBEIRO, Francisco de Paula. Mappa Geographico da Capitania do Maranham, que pode servir de Memoria sobre a População, Cultura, e couzas mais notáveis da mesma Capitania. Fundação Biblioteca Nacional - RJ. Imagem disponível em http:// www.bn.br.

Com foco nos pousos, importante é o estudo de Laurent Vidal (2016, p. 400-419) que os define como "filhos dos caminhos", "formas nascida da espera dos homens em deslocamento" e dedicados ao "acolhimento dos homens em pausa". Introduzindo uma variável nova de análise, o tempo, põe luz nos ritmos que deram origem a esses abrigos. Sendo uma categoria de tempo, o ritmo e as rupturas que ele contém definem os pousos como uma forma de tempo modelado. Um tempo pensado espacialmente para acolher a imobilização temporária de um fluxo no decorrer de um percurso. Interessante é o exemplo do Pouso de Camapuã, fundado em 1720 no caminho das monções para Cuiabá, entre as cabeceiras dos rios Sanguessuga e Camapuã. Ponto de apoio nos $14 \mathrm{~km}$ de varação, Camapuã vai acolher uma fazenda para criação de gado e plantação de alimentos com intuito de abastecer os comboios, funcionando inclusive para consertar as canoas.

Às constatações supracitadas somam-se as de Tiago Kramer de Oliveira (2012), com foco nas ses-marias concedidas ao longo dos caminhos e rios que abasteciam os viajantes de Goiás para Mato Grosso. Mostra uma rede de fazendas e sítios relacionados ao plantio de gêneros de primeira necessidade e também à criação de animais para abastecimento dos viajantes, posicionandose estrategicamente ao sabor do tempo das jornadas diárias. 
Com foco na cultura material, Maria Aparecida Borrego investigou em recente estudo o conteúdo das bagagens das monções que do Porto de Araritaguaba (atual Porto Feliz) destinavam-se ao Mato Grosso e Goiás (Borrego, 2016), completando o cotidiano das viagens.

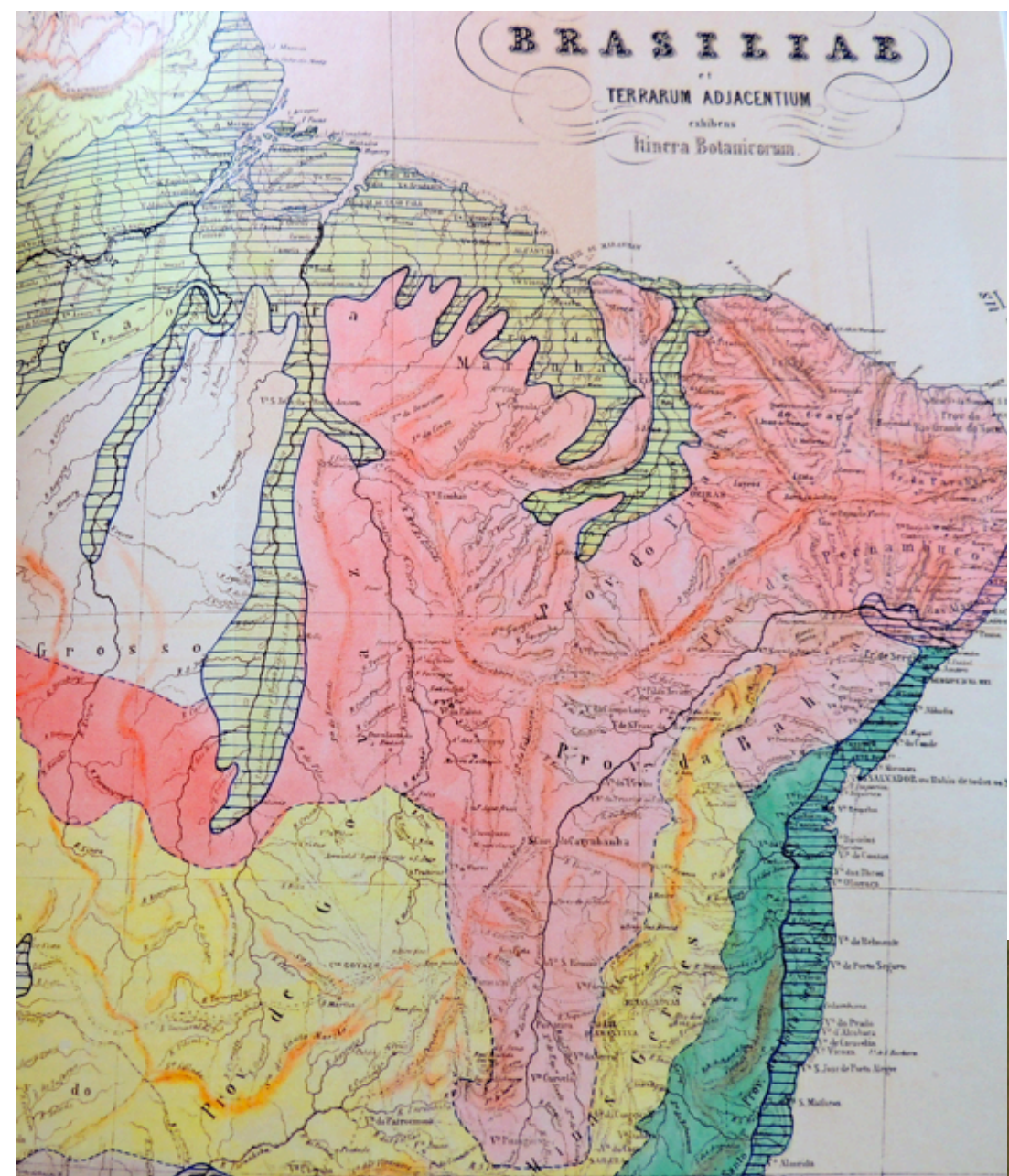

Figura 12. Detalhe do mapa de Carl Friedrich Philipp Von Martius, Flora Brasiliensis, Enumeratio Plantarum, vol. I, Tabula Geographica, 1840-1906. No centro do mapa, vê-se o Rio Tocantins nas suas interfaces macrorregionais com as Capitanias do Grão-Pará, Goiás e Bahia (via Rio São Francisco). 0 mapa de von Martius permite também aferir a heterogeneidade dos biomas brasileiros, aqui em causa a caatinga. Fonte: en Lorelay Kury et al. (org), Sertões adentro: viagens nas caatingas séculos XVI a XIX,Rio de Janeiro: Andrea Jakobsson, 2012, p. 216.

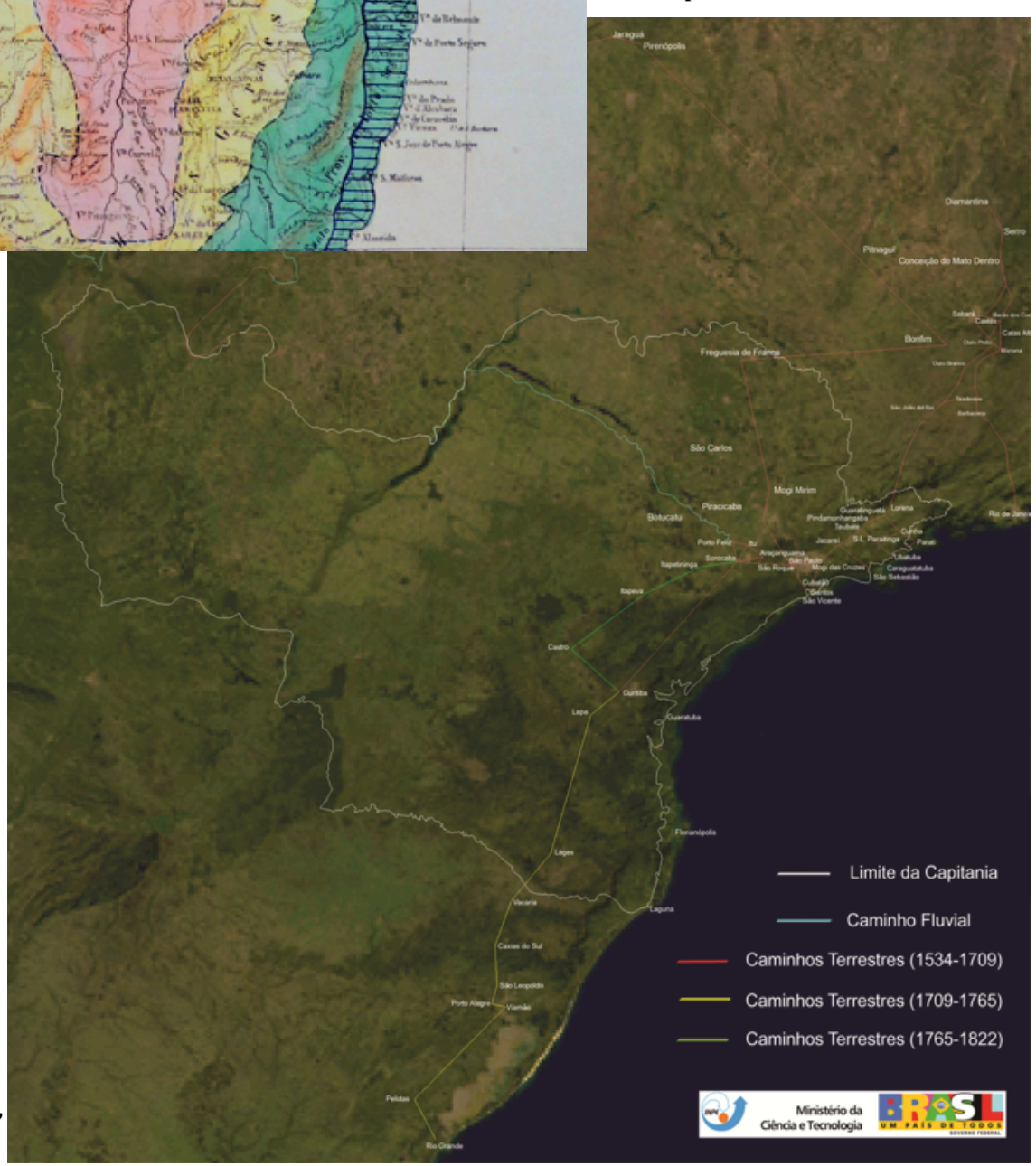

Figura 13. Conexões

macroterritoriais e intermodais do Caminho do Viamão a Goiás e Cuiabá. Embora não representado no mapa, é importante lembrar que, via rios Tietê/ Paraná/ Paraguai e caminhos terrestres ia-se de São Paulo a Assunção do Paraguai e dali a Potosi. Reconstituição em mapas de satélite realizada em parceria com o INPE. Fonte: Beatriz Bueno, "Dilatações dos confins", Anais do Museu Paulista, v. 17, n. 2, 2009, p. 290. 


\section{As capitanias fronteiriças do Mato Grosso e de São José do Rio Negro como lugar de encontros culturais, trocas e hibridismos}

Nesse diapasão, interessante também é o caso da Capitania do Mato Grosso, não apenas nas suas interfaces históricas com São Paulo, mas com América Espanhola.

Zona de fronteira, em Cuiabá até hoje se fala uma língua híbrida, mesclando termos castelhanos a dialetos indígenas, portugueses e africanos. 0 linguajar cuiabano acaba de ser registrado como patrimônio imaterial em âmbito estadual, mas pouca ênfase foi dada ao acento castelhano ali permanente.

Estudos recentes têm posto em evidência o potencial de conectividade de Cuiabá por meio de uma articulada rede fluvial e terrestre, intermodal. Cáceres, a antiga Vila Maria do Paraguai, vem sendo analisada na sua vocação mercantil desde o século XVIII, justamente por se situar à beira do rio Paraguai, tradicionalmente lido na chave da fronteira política, quando mereceria ser investigado na chave da ideia de fronteira como privilegiada "zona de encontro entre culturas".

A despeito das inúmeras dificuldades fruto das enormes distâncias, trocava-se muito comercial e culturalmente. Levando-se em conta que a viagem de São Paulo a Cuiabá demorava seis meses para ir e outros seis para voltar, não surpreende imaginar o poder de atração de Assunção e outros núcleos vizinhos para a vilas do Mato Grosso, lembrando que a fronteira com a Bolívia estendia-se por 700 km e que os rios Guaporé e Madeira eram navegáveis e conectados ao rio Paraguai.

Para dar vida aos caminhos e pousos, interessante seria cotejar a cartografia com os diários e desenhos resultantes das inúmeras expedições, desde a Viagem Filosófica de Alexandre Rodrigues Ferreira até a Expedição de Langsdorff. 0 acervo do Museu Bocage em Lisboa (Teixeira \& Papavero, 2003) guarda a parte dos desenhos Viagem Filosófica de Alexandre Rodrigues Ferreira correspondentes aos rios Paraguai, Guaporé e Madeira rumo à Bacia Amazônica, dando a ver a cara das vilas - Vila Maria do Paraguai, Albuquerque, Cuiabá, Vila Bela da Santíssima Trindade, Cazalvasco numa espécie de história em quadrinhos a ser cotejada com a cartografia supracitada.

Por outro lado, a Coleção Alexandre Rodrigues Ferreira da Fundação Biblioteca Nacional completa o itinerário ao salvaguardar os desenhos de Freire e Codina referentes à Bacia Amazônica, na sua passagem por Barcelos e chegada a Belém. As coleções entrecruzadas permitem assim acompanhar a navegabilidade e comunicação entre as Bacias do Prata e Amazônica, demonstrando interfaces macroterritoriais e possibilidades de um efervescente mercado interno dentro da própria América Portuguesa, sem falar com as áreas vizinhas.

Interessante interpretar mapas e relatos à luz do conceito de "paisagem toponímica" cunhado por Iris Kantor, considerando que o nome atribuído aos lugares revela seu caráter e podem representar pistas importantes sobre o cotidiano das viagens por rios navegáveis, trilhas e caminhos terrestres, bem como sobre as formas de enraizamento e fertilização entre nativos e ádvenas (Kantor, 2009, p. 39-61).

Na perspectiva de uma História Global americana ou macrorregional intercapitanias (Bueno, 2016), seria conveniente analisar a rede urbana em seu conjunto e entender o papel de certos pontos nodais na lógica dos fluxos, dentre eles Belém e Barcelos, cuja materialidade da sua arquitetura civil e religiosa espelha o papel diferenciado que cumpriam. Barcelos se insere nessa lógica como uma segunda capital macroterritorial, sede da nova Capitania de São José do Rio Negro decorrente das políticas do consulado pombalino. A série cartográfica, iconográfica e etnográfica resultante da Expedição de Alexandre Rodrigues Ferreira dá a ver o prospecto dos aglomerados, apequenados diante da floresta tão majestosa. Obviamente nem todas as povoações têm as mesmas características de Belém e Barcelos (com seus armazéns vinculados às Cias. de Comércio), predominando construções mais modestas, com cobertura de palha, em evidente simbiose com o universo indígena predominante.

Embora sejam "picadas de inseto em pele de elefante", feliz expressão de Walter Rossa referindose às cidades portuguesas na Índia, lida em conjunto, a rede urbana revela sua eficácia política no desenho da fronteira Oeste e Norte da América Portuguesa (Araújo, 1992, p. 132). 
Na pujança da floresta, pontuando largos rios em ritmos espaçados, essa frágil rede urbana deu conta do recado. A lusitanização dos topônimos nativos (Kantor, 2009, p. 53), ainda hoje persistente, reforça simbolicamente a capilaridade dos desígnios estratégicos do projeto pombalino: Vila Viçosa da Tutóia, Nazaré do Mearim, Monção, Viana, Bragança, Ourém, Vigia, Cametá, Baião, Oeiras, Soure, Monsaraz, Breves, Portel, Souzel, Pombal, Gurupá, Macapá, Marzagão, Almeirim, Prainha, Alter do Chão, Aveiro, Santana, Óbidos, Vila Branca, Silves, Serpa, Borba, Moura, Barcelos, Tomar, Loreto, São José das Marabitenas, Olivença, Tabatinga.

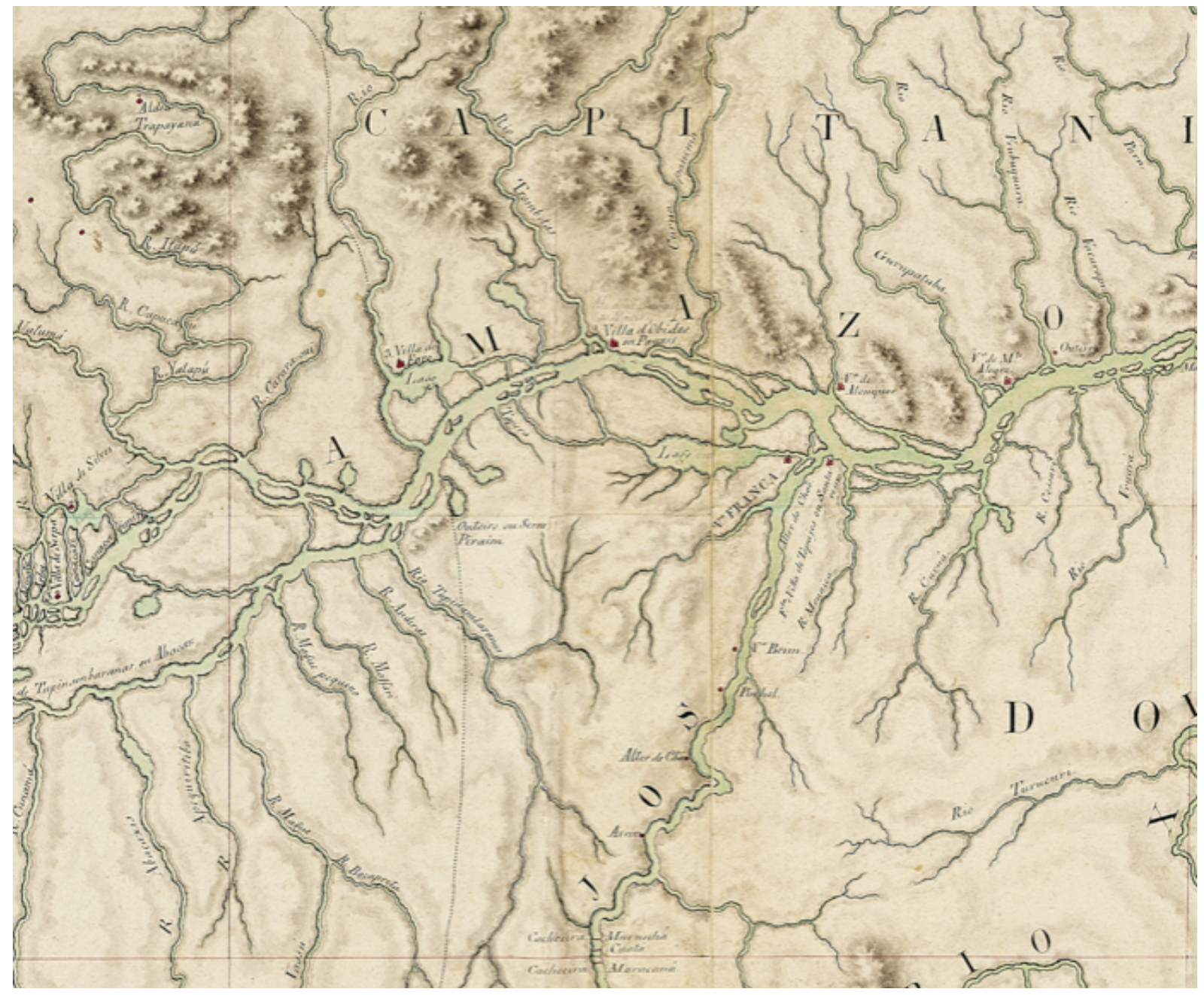

Figura 14. Rede urbana na Bacia Amazônica. Detalhe da [Carta Geral do Brasil]. — Escala [ca.1:2 600 000], 5 graus de latitude $=[21.7 \mathrm{~cm}] . \quad$, [1797]. — 1 mapa em 16 folhas coladas : ms., color. ; 199 x 202 cm.; Direcção da Arma de Engenharia.

No entanto, convém não nos deixarmos iludir pela falsa impressão de se tratar de vilas à portuguesa, quando na verdade predominou na fecundação-cruzada os traços indígenas na arquitetura, no linguajar, nos costumes.

Em estudo recente demonstramos que o resultado não é pouco. Envolve toda uma parte tomada dos Vice-Reinados de Lima e de Santa Fé (Peru e Colômbia, respectivamente) a partir de Ega (Tefé), ponto estratégico da Bacia Amazônica onde afluíam três cursos d'água (Bueno, 2012). Em teoria, significou mais território; na prática, significou a salvaguarda de $2.400 \mathrm{~km}$ de acesso exclusivo ao Oceano Atlântico. A perda de boa parte do Rio Amazonas pelos espanhóis não correspondia apenas em abrir mão de um território abstrato, mas de entregar aos portugueses a rota mais fácil de acesso à Europa, muito melhor que o percurso inverso, via rio Napo-Quito e dali a Lima. Ganhou-se cerca de $400 \mathrm{~km}$ do Japurá ao rio Javarí onde foi estabelecido o Forte de Tabatinga. Não menos importante, significou a salvaguarda das fronteiras Norte e Oeste na sua comunicabilidade envolvendo duas bacias transcontinentais com interfaces em todas as direções. 


\section{Sobre os negócios e a rede urbana nos Sertões do Norte}

Sobre os Sertões do Norte, estudos recentes dão-lhes outra face para além do vazio e da pobreza estereotipados no imaginário literário. Nathália Montenegro Diniz (2015) inova ao abordar uma macrorregião - os Sertões do Norte - , extrapolando fronteiras políticas e acadêmicas. Põe luz numa significativa rede de fazendas margeando ribeiras em área até então pensada como um grande vazio.

Figura 15. Rede de fazendas ao longo das ribeiras dos Sertões do Norte.

Fonte: Nathália M. Diniz (2015). Um sertão entre tantos outros. São Paulo: Versal.

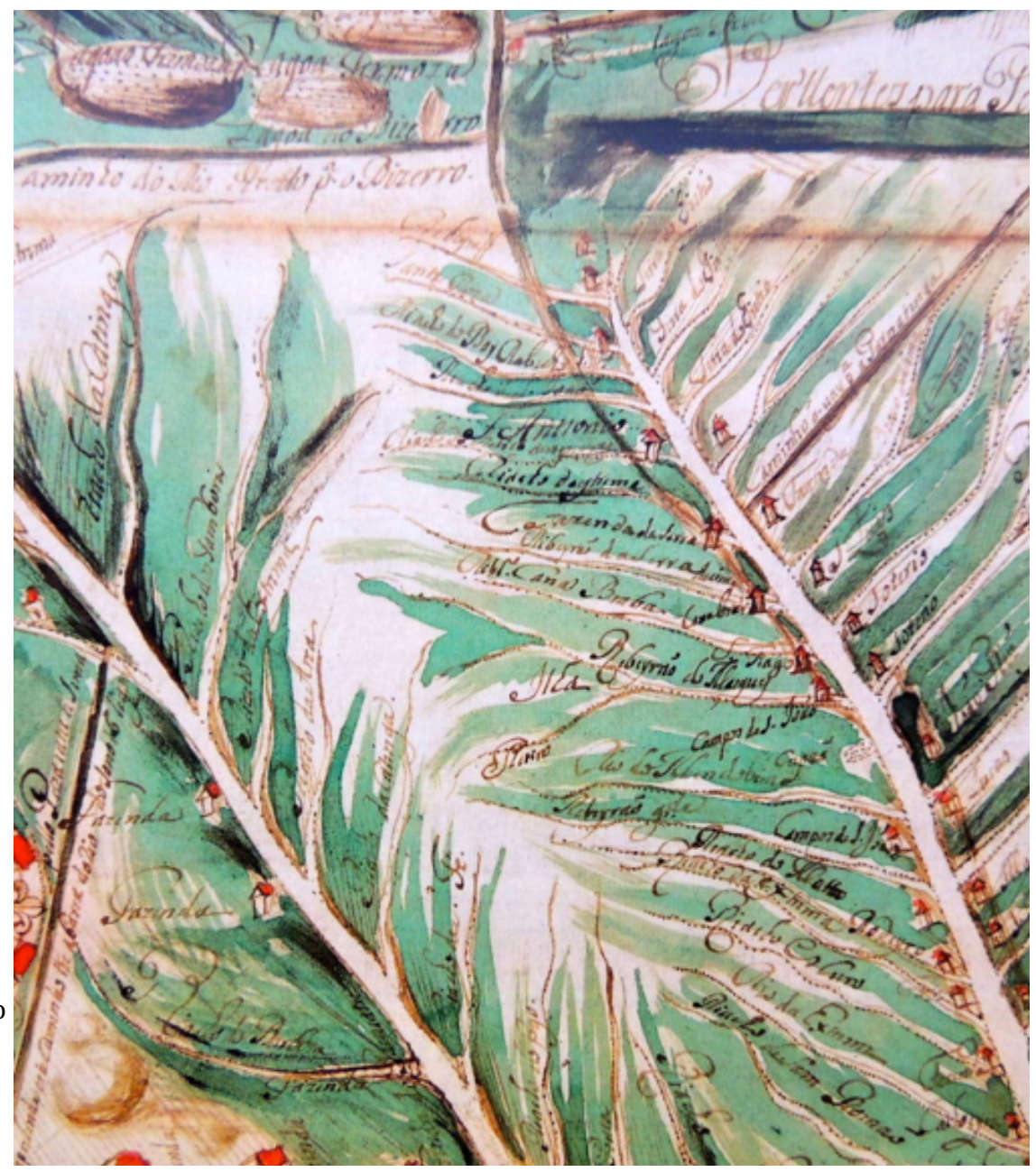

Para além da importância do inventário em si, a narrativa ensejada pela rede de casas de fazendas, engenhos de rapadura e casas de farinha versa sobre o processo de formação social dos Sertões do Norte, sobre sua diversidade geográfica (física e humana), sobre as redes de comunicação terrestres (caminhos, veredas, estradas) e fluviais que lhe articulavam, sobre a rede urbana de lugares, capelas, freguesias, vilas, cidades, pousos, feiras, barreiras, registros e passagens. Nas entrelinhas do discurso, Nathália Diniz introduz uma série de novidades: interdependência entre o mundo rural e o urbano; homens em movimento numa economia em movimento; complexa cadeia produtiva e divisão técnica e social do trabalho; práticas e dinâmicas relativas aos fluxos de mercadorias e formas de organização do comércio, mostrando como as comitivas que acompanhavam a gadaria transportavam gêneros variados, dando colorido a um mercado interno até então inexplorado desse ponto de vista. Por meio do inventário de um artefato da cultura material, a autora desvenda outros tantos, desmontando teses sobre o isolamento e a desolação impostos por uma geografia agreste. Revela assim uma complexa "civilização do couro", rompendo com estereótipos consagrados pela historiografia tributária de Capistrano de Abreu e dos Institutos Históricos e Geográficos regionais, eternizados pelos memorialistas, folcloristas e romancistas, mostrando o papel da vasta região interiorizada dos atuais estados do Maranhão, Piauí, Ceará, Rio Grande do Norte, Paraíba, Pernambuco e Bahia para o resto do Brasil e do mundo urbanizado. Afinal, se a carne verde e salgada alimentava os circuitos urbanos do litoral e das áreas de mineração, o gado era força motriz de carros de bois e engenhocas, o couro embalava o tabaco destinado ao escambo de escravo na 
África, bem como era matéria prima para a confecção de inúmeros artefatos de uso cotidiano (bolsas, malas, arreios, selas, chicotes, solas de sapato, assentos e encostos de cadeiras, chapéus e outros elementos de indumentária) aqui e alhures. Essa interdependência entre o mundo rural e o urbano recoloca a interpretação das economias regionais em outro patamar de discussão. Espacializadas e alinhadas numa rede de caminhos e ribeiras, as fazendas entram num circuito de relações mais amplas e ganham importância nos estudos de história da urbanização, de história social e cultura material. A cartografia antiga permitiu reconstituir espacialidades e territorialidades que nossa memória não alcança. A cartografia somada aos relatos oficiais e dos viajantes permitiu pincelar na imaginação do leitor as dificuldades das longas jornadas das boiadas em caminhos que se acomodavam à paisagem, contornando serras, adentrando boqueirões e margeando ribeiras que ao mesmo tempo hidratavam a gadaria e a alimentavam de sal. A narrativa cheia de vida convida o leitor a percorrer os caminhos junto das ribeiras e vivenciar a lida diária, as agruras das longas jornadas, o cotidiano das viagens com boiadas de até 200 reses em direção às feiras e portos do litoral. Nas ribeiras e estradas pode-se imaginar - em meio ao gado tangido por vaqueiros, tangedores e guias - a malotagem dos comboios de mercadorias e o comércio correlato. Tangia-se o gado para que não saísse do caminho ou se amontoasse. Pode-se imaginar, a cada 4 a 5 léguas, as pausas para descanso da comitiva em lugares onde se pudesse arranchar. Dali a passagem da boiada ao passador e dele ao marchante até as feiras destinadas às trocas mercantis e vilas onde estavam os matadouros, curtumes e oficinas de salga. Nesse sentido, o frescor do livro resulta das tantas novidades nele contidas que lastreiam a hipótese central que o intitula: a ideia de um sertão entre tantos outros. No plural, com geografias diversificadas e antropizadas heterogeneamente, essas zonas do Norte ganham contornos à medida em que se entretecem a outras tantas do Brasil afora. Falar de "sertão nordestino" não só empobreceria a leitura por homogeneizar e delimitar um território variado e permeável, como significaria incorrer em anacronismo por se tratar de uma terminologia forjada no século XX e carregada de ideologias pejorativas. Nem mesmo a caatinga mostra-se um bioma homogêneo, também ela revela-se plural, vez por outra menos árida e sazonalmente verdejante. No livro, a caatinga mostra-se irrigada por uma capilar rede de ribeiras que se entrelaça a caminhos, veredas e estradas e alinhava complexa rede de núcleos urbanos e sesmarias voltadas ao criatório, configurando-se como unidades administrativas, outra novidade e contribuição da autora. Sobre a heterogeneidade da caatinga, o estudo coordenado por Lorelay Kury dá a medida da diversidade fitomorfológica do bioma (Kury et al., 2012).

Sobre os Sertões do Norte, completam o cenário os estudos de Damião Esdras Arraes (2016, p. 278 e 2017) que incluem outros ingredientes nessa complexa e heterogênea paisagem em suas interfaces com as capitanias do entorno, georreferenciando a plural rede urbana de missões religiosas, capelas filiais, freguesias, curatos amovíveis, freguesias coladas, vigarias da vara, freguesias de índios, julgados, vilas, vilas de índios, cidades, em meio a pousos, passagens, registros, feiras, fazendas, engenhos, currais, minas de salitre, arraiais de mineração de ouro e diamantes, etc, dando a medida da urdidura da trama e rediscutindo a imagem de "vazio" "incógnito" e "pobre" que rondou a historiografia sobre o semiárido desde Capistrano de Abreu. Sua contribuição georreferenciada amplia nosso conhecimento inclusive sobre as redes de comunicações, na sua hierarquia plural, incluindo Estradas Gerais, caminhos, ribeiras navegáveis e mensurando o fluxo de pessoas e mercadorias transportadas. Seu objetivo é cartografar regressivamente a lógica e a dinâmica dos fluxos que justificaram uma rede urbana macroterritorial. Para além do gado, Arraes revela os inúmeros negócios entre capitanias ali promovidos (envolvendo o comércio de artefatos variados, inclusive o sal da terra e o salitre ali extraídos e até então inexplorados pela historiografia).

Comparativamente ao mapa do Atlas da América Lusa de Tiago Gil mostrado no início do presente artigo, fica evidente que a rede de núcleos - para além das vilas e cidades - permite viasualizar uma urbanização mais capilar e interiorizada do que imaginávamos.

Na mesma linha, só que com recorte menos alargado, inserem-se os estudos de Catarina Agudo Menezes (2010 e 2017) sobre Alagoas. Neles a autora desconfia das assertivas sobre as representações de Alagoas como polo açucareiro emanadas do Instituto Histórico Geográfico Brasileiro e regional, mostrando, desde o século XVII, a interdependência do criatório com a economia do açúcar em pleno litoral (junto da foz do São Francisco). Apoiando-se no mapa de Georg Marcgraf, quantifica e qualifica os tantos currais e engenhos ali existentes. 
A mesma interdependência e complementariedade de economias observa-se nas margens dos rios Parnaíba, Itapecuru e Mearim, entre Maranhão, Piauí e Bahia. Samir Roland (2016, p. 284-285) vem demonstrando a rede de fazendas, engenhos de açúcar e currais de gado que destinavam-se a abastecer ao mesmo tempo o mercado interno e o comércio atlântico.

Essas teses somadas e, quem sabe seus resultados georreferenciados, alteram o cenário da História da Urbanização no período colonial, revelando um Brasil mais urbano e menos arquipelágico do que parecia à primeira vista.

\section{Referências}

Araújo, M. L. V. de (2006). Os Caminhos da riqueza dos paulistanos na primeira metade do oitocentos. São Paulo: Hucitec, Fapesp.

Araújo, R. M. de (1992). As cidades da Amazónia no século XVIII. Belém, Macapá e Mazagão. Porto: UNL.

Arraes, E. (2016). "Pensar con los ojos sertões, cartografar territórios e representar paisagens" In: Caderno de Resumos VI EIHC - Encontro Internacional de História Colonial (p. 278). Salvador, BA, Brasil, 6.

Arraes, E. (2017). Ecos de um suposto silêncio: paisagem e urbanização dos certoens do Norte, c. 1666-1820. Tese de Doutorado, Universidade de São Paulo (USP/FAU), São Paulo, SP, Brasil.

Bayón, D. (1982). Pensar con los ojos. México: FCE.

Blaj, I. (2002). A trama das tensões: o processo de mercantilização de São Paulo colonial (1681-1721). São Paulo: Humanitas, Fapesp.

Borrego, M. A. (2010). A teia mercantil. São Paulo: Alameda.

Borrego, M. A. (2016). "Viandantes e carregações entre a cidade de São Paulo e as minas de Cuiabá" In: Anais do EIHC - Encontro Internacional de História Colonial. Salvador, BA, Brasil.

Borsoi, D. F. (2010). Nos traços do cotidiano. Cunha entre as vilas de serra acima e os portos da marinha. Dissertação de Mestrado, Universidade de São Paulo (USP/FAU), São Paulo, SP, Brasil.

Braudel, F. (1995). Civilização material, economia e capitalismo: séculos XV-XVIII (3v.). São Paulo: Martins Fontes.

Bresciani, M. S. (2001). "Identidades inconclusas no Brasil do século XX - fundamentos de um lugar-comum”. In M. S. Bresciani \& M. Naxara. Memória e (res)sentimento (pp. 403-429). Campinas: Editora da Unicamp.

Bueno, B. P. S. (2009). Do borrão às agudas: os engenheiros militares e a representação da Capitania de São Paulo. Anais do Museu Paulista, 17 (2), p. 111-153. São Paulo.

Bueno, B. P. S. (2011). Desenho e desígnio: o Brasil dos engenheiros militares (1500-1822). São Paulo: Edusp, Fapesp.

Bueno, B. P. S. (2012). Caminhos da História da Urbanização. Dossiê Anais do Museu Paulista, v. 20.

Bueno, B. P. S. (2012). A arquitetura das fronteiras do Brasil: duas faces de um mesmo problema. Arquitextos, Ano 13, set.

Bueno, B. P. S. (2015). A longo dos rios: os primeiros sítios urbanos de São Paulo. Da Cultura, ano XIV, n. 25, pp. 35-40.

Bueno, B. P. S. (2016). 0 Brasil-colônia: em que medida mais urbano do que parece à primeira vista?. In: Anais do I Congreso iberoamericano de historia urbana ciudades en el tiempo: infraestructuras, territorios, patrimônio (pp.825-834). Pontifícia Universidad Católica de Chile, Chile, 1.

(C) Labor \& Engenho, Campinas [SP] Brasil, v.11, n.3, p.242-262, jul./set. 2017. 
Bueno, B. P. S. (2016). Aspectos do mercado imobiliário em perspectiva histórica: São Paulo (1809-1950). São Paulo: Edusp.

Burke, P. (2006). Hibridismo cultural. São Leopoldo: Unisinos.

Camargo, A. M. (org.) (2016). São Paulo de outros tempos. São Paulo: CIEE.

Certeau, M. de (1980). L'invention du quotidien. Paris.

Diniz, N. M. (2015). Um sertão entre tantos outros. São Paulo: Versal.

Furtado, J. (2016). Metamorfoses da colonização: o rio Tocantins e a expansão para o oeste em mapas e relatos (século XVIII), Tempo, 22 (40), pp. 367-399. (Niterói, online).

Gianesella, R. (2008). Paisagens no tempo: vilas litorâneas paulistas. Dissertação de Mestrado, Universidade de São Paulo (USP/FAU), São Paulo, SP, Brasil.

Gil, T., \& Barleta, L. (2016). Atlas histórico da América lusa. Porto Alegre: Ladeira Livros.

Gruzinski, S. (2014). As quatro partes do mundo. São Paulo: Edusp.

Harley, J. B. (2005). La nueva naturaleza de los mapas. México: FCE.

Kantor, I. (2009). Cartografia e diplomacia: usos geopolíticos da informação toponímica (1750-1850). Anais do Museu Paulista, 17 (2), pp. 39-61. São Paulo.

Kato, A. T. (2017). Elites, negócios e imóveis no plural: São Paulo nas décimas urbanas e listas nominativas. Tese de Doutorado, Universidade de São Paulo (USP/FAU), São Paulo, SP, Brasil.

Kok, G. (2004). O sertão itinerante: expedições da Capitania de São Paulo no século XVIII. São Paulo: Hucitec, Fapesp.

Kury, L. et al. (orgs.) (2012). Sertões adentro: viagens nas caatingas séculos XVI a XIX. Rio de Janeiro: Andrea Jakobsson.

Matos, R. (2015). Política e negócios em São Paulo: da abertura dos portos à Independência (1808/1822). Tese de Doutorado, Universidade de São Paulo (USP/FFLCH), São Paulo, SP, Brasil.

Menezes, C. (2010). Entre palavras e desenhos. Dissertação de Mestrado, Universidade Federal de Alagoas, Maceió, AL, Brasil.

Menezes, C. Alagoas além do açúcar. Tese de Doutorado, Universidade de São Paulo (USP/FAU), São Paulo, SP, Brasil.

Monteiro, J. (1994). Negros da terra. Bandeirantes e índios nas origens de São Paulo. São Paulo: Companhia das Letras.

Moura, D. S. de (2012). De uma freguesia serra acima à costa atlântica: produção e comércio da aguardente na cidade de São Paulo (1765-1822). Topoi, 13 (24), pp. 73-93.

Moura, D. S. de (2017). Santos: um porto entre dois impérios. In A. M. Camargo (org.). São Paulo de outros tempos (pp. 155-172). São Paulo: CIEE.

Oliveira, T. K. de (2012). Desconstruindo velhos mapas, revelando espacializações: a economia colonial no centro da América do Sul (primeira metade do século XVIII). Tese de Doutorado, Universidade de São Paulo (USP/ FFLCH), São Paulo, SP, Brasil.

Reis, N. G. (2013). As minas de ouro e a formação das Capitanias do Sul. São Paulo: Via das Artes. 
Reis, N. G. (2014). O Caminho do Anhanguera. São Paulo: Via das Artes.

Ribeiro, F. V. A. (2015). Vilas do planalto paulista: a criação de municípios na porção meridional da América Portuguesa (séc. XVI-XVIII). Tese de Doutorado, Universidade de São Paulo (USP/FFLCH), São Paulo, SP, Brasil.

Roland, S. (2016). “Historiografia e a colonização do Vale do Parnaíba: o processo de consolidação da ocupação e do povoamento (1720-1759)" In: Caderno de Resumos VI EIHC - Encontro Internacional de História Colonial, (pp. 284-285). Salvador, BA, Brasil, 6.

Santos, M. (1996). A natureza do espaço (4a. ed). São Paulo: Edusp.

Silva, R. (2013). Sobre taipas e textos: um estudo sobre as narrativas a respeito da cidade de São Paulo. São Paulo: Alameda.

Teixeira, D. M., \& Papavero, N. (2016). A iconografia da "Viagem Philosophica" de Alexandre Rodrigues Ferreira no Museu Bocage. In J. P. M. Soares, \& C. Ferrão (Orgs.) (2003). Viagem ao Brasil de Alexandre Rodrigues Ferreira (1a. ed) (v.1) (pp. 1-159). Petrópolis: Kappa. In M. L. V. de Araújo (2006). Os Caminhos da riqueza dos paulistanos na primeira metade do oitocentos. São Paulo: Hucitec, Fapesp.

Vidal, L. (2016). "A gênese dos pousos modernos. Considerações sobre as formas (urbanas) nascidas da espera". Tempo, 22 (40), pp. 400-419, mai-ago. (Niterói, online).

Vilardaga, J. C. (2014). São Paulo no império dos felipes. Conexões na América Meridional (1580-1640). São Paulo: Intermeios, Fapesp.

Vilardaga, J. C. (2016). "Na bagagem dos peruleiros: inventários dos bens de contrabando do caminho proibido de São Paulo ao Guairá”, In: Anais do EIHC - Encontro Internacional de História Colonial. Salvador, BA, Brasil. 